\title{
REVIEW \\ Glial contributions to visceral pain: implications for disease etiology and the female predominance of persistent pain
}

\author{
KN Dodds ${ }^{1}$, EAH Beckett ${ }^{1}$, SF Evans ${ }^{2,3}$, PM Grace $^{2,4}$, LR Watkins $^{4}$ and MR Hutchinson ${ }^{1,5}$
}

In the central nervous system, bidirectional signaling between glial cells and neurons ('neuroimmune communication') facilitates the development of persistent pain. Spinal glia can contribute to heightened pain states by a prolonged release of neurokine signals that sensitize adjacent centrally projecting neurons. Although many persistent pain conditions are disproportionately common in females, whether specific neuroimmune mechanisms lead to this increased susceptibility remains unclear. This review summarizes the major known contributions of glia and neuroimmune interactions in pain, which has been determined principally in male rodents and in the context of somatic pain conditions. It is then postulated that studying neuroimmune interactions involved in pain attributed to visceral diseases common to females may offer a more suitable avenue for investigating unique mechanisms involved in female pain. Further, we discuss the potential for primed spinal glia and subsequent neurogenic inflammation as a contributing factor in the development of peripheral inflammation, therefore, representing a predisposing factor for females in developing a high percentage of such persistent pain conditions.

Translational Psychiatry (2016) 6, e888; doi:10.1038/tp.2016.168; published online 13 September 2016

\section{FROM 'HYSTERIA' TO A MOLECULAR UNDERSTANDING OF FEMALE PAIN}

Historical descriptions of chronic debilitating pain without obvious visible cause were originally restricted to females, and dated back over 2000 years to the era of renowned Greek physician Hippocrates (460-370 BC). Episodes of severe emotional and physical distress in women were diagnosed as 'hysteria', a condition attributed to the movement of the uterus outside of the pelvis (the 'wandering womb'). ${ }^{1}$ Towards the end of the nineteenth century, the stigma surrounding female hysteria diminished owing to accumulating evidence that men could also suffer from persistent pain, work which was largely pioneered by Sigmund Freud (1856-1939). ${ }^{2}$ Considering pain as sexindependent in this context, along with general medical advances from the mid-twentieth century, has contributed to an immense expansion in our understanding of the mechanisms underlying the development of persistent pain. Notably, this is now known to involve bidirectional signaling between neurons and glia within the central nervous system (CNS).

However, a key discrepancy that remains in the literature is the clear over-representation of females among patients with persistent pain. There is an almost unanimous consensus that women are not only more sensitive in detecting painful stimuli, but are also the predominant sex with the most common painful disorders. $^{3-6}$ This includes, but is not limited to, conditions associated with neuropathic pain, musculoskeletal pain (such as back pain, fibromyalgia, osteoarthritis and complex regional pain syndrome), orofacial pain (including temporomandibular joint pain), abdominal and pelvic pain (such as irritable bowel syndrome, painful bladder syndrome and dyspareunia) and headache/migraine. ${ }^{5}$

Extensive epidemiological, clinical and experimental evidence implicates several biopsychosocial factors as contributing to the disparity in pain susceptibility across the sexes. ${ }^{4}$ Despite this, a dichotomy exists in the pain research field at large, where the vast majority of preclinical studies have characterized pain models using male subjects only. ${ }^{7}$ Moreover, evidence implicating neuroimmune signaling in the development of persistent pain has primarily been acquired using animal models of neuropathic and somatic inflammatory pain. This has included, but is not restricted to, muscle inflammation, spinal cord injury, peripheral nerve injury, arthritis, bone cancer and chemotherapy. Although many of these pathologies are important for understanding female pain, there is a lack of research into the large number of female-dominant conditions that stem from the viscera. Consequently, the specific biological mechanisms underlying the predisposition of females to persistent pain remain elusive.

It is possible that past research generalizing nociceptive mechanisms across the sexes has limited our approach in effectively treating female pain. Is it appropriate to assume that females process pain via identical mechanisms to males? Can we learn from, adapt and update aspects of the ancient Greek philosophy, by regarding female pain as a fundamentally distinct entity? And, to what extent do the sex-specific anatomical and neuroendocrine systems influence the heightened sensitivity of females to persistent pain?

To consider these questions, this review provides a summary of neuroimmune contributions, specifically those provided by astrocytes and microglia, to persistent pain signaling within the spinal

${ }^{1}$ Discipline of Physiology, School of Medicine, University of Adelaide, Adelaide, SA, Australia; ${ }^{2}$ Discipline of Pharmacology, School of Medicine, University of Adelaide, Adelaide, SA, Australia; ${ }^{3}$ Pelvic Pain SA, Norwood, SA, Australia; ${ }^{4}$ Department of Psychology and Neuroscience, Center for Neuroscience, University of Colorado Boulder, Boulder, CO, USA and ${ }^{5}$ ARC Centre of Excellence for Nanoscale BioPhotonics, University of Adelaide, Adelaide, SA, Australia. Correspondence: KN Dodds, Discipline of Physiology, School of Medicine, University of Adelaide, Medical School North 416, Frome Road, Adelaide, SA 5005, Australia.

E-mail: kelsi.dodds@adelaide.edu.au

Received 2 June 2016; revised 14 July 2016; accepted 22 July 2016 
cord. The concept that female sex hormones may modulate central neuroimmune signaling is then discussed, and that variations in these processes may have relevance for femaledominant pain conditions, as exemplified by several visceral inflammatory diseases. In addition, the dorsal root reflex is re-explored as a central driver of peripheral neurogenic inflammation, leading to the hypothesis that sensitized spinal glia might contribute to, and predispose, a subpopulation of females to persistent inflammatory pain.

\section{PERSISTENT PAIN ARISES FROM CENTRAL SENSITIZATION}

Pain is a complex, unpleasant sensory and emotional experience that arises in response to, or is described in terms of, tissue damage. $^{8}$ Distinct from the well-established protective and adaptive functions of acute pain, pain persisting beyond tissue healing is maladaptive and serves no known physiological function. In contrast to acute pain, the mechanisms involved in the development and maintenance of persistent pain are not fully understood. One potential mechanism that has received detailed investigation is the process of 'central sensitization', whereby long-lasting molecular changes cause amplification of pain signaling by nociceptive neurons within the CNS. Central sensitization can include conditions of both hyperalgesia (heightened pain to a previously noxious stimulus) and allodynia (pain caused by a normally innocuous stimulus). ${ }^{9,10}$ It is now acknowledged that the development of central sensitization engages not only neuronal, but also glial processes. Hence, the following sections outline the rationale for considering persistent pain to be a 'gliopathy', ${ }^{11}$ in addition to the previously described 'neuropathy'.

\section{GLIA AND THE TETRAPARTITE SYNAPSE SUPPORT THE MAINTENANCE OF CNS HOMEOSTASIS}

Glia are a non-neuronal, immune-like cell population that constitute the vast majority of cells within the CNS. They comprise satellite glial cells in the ganglia, and microglia, astrocytes and oligodendrocytes within the spinal cord and brain. The anatomical co-localization of astrocytes and microglia in the spinal cord, combined with pre- and postsynaptic neurons, forms a key site of interaction termed the 'tetrapartite synapse'. ${ }^{12,13}$ Each cell within this functional unit reciprocally signals to another, contributing to a 'neuroimmune communication' that allows glia to respond rapidly to disruptions in neuronal signaling. ${ }^{14,15}$ The reactivity state and control of astrocytes and microglia is therefore critical in maintaining healthy CNS activity.

\section{DYSREGULATION OF HEALTHY GLIAL ACTIVITY CONTRIBUTES TO THE DEVELOPMENT OF PERSISTENT PAIN}

Following injury and aberrant nociceptive events, microglia and astrocytes increase their expression and secretion of various proinflammatory cytokines and chemokines. ${ }^{15}$ The stimulation of glial cells can occur by neurokine products released as a result of tissue injury, or by neurotransmitters released from activated neurons. Many of the proinflammatory responses of glia are important in protecting against challenges that disrupt the homeostatic balance of the CNS, such as during the sickness response- a constellation of adaptive behaviors and physiological responses that promote recovery from illness. ${ }^{16}$ However, under certain conditions, glial reactivity is not advantageous and can instead be detrimental to neuronal function, such as during the manifestation of persistent pain.

In response to strong or persistent receptor stimulation, microglia switch from a surveillance state to an active response state, and astrocytes transition from a regulatory to reactive state. ${ }^{11}$ Under these circumstances, the release of proinflammatory mediators by glia can contribute to ongoing nociception, by inducing long-lasting plastic changes of synaptic connectivity that enhances the transmission of ascending nociceptive information. As such, glia and their products are sufficient to create exaggerated pain. This has been shown where intrathecal transfer of highly reactive microglia alone, or injection or induction of their proinflammatory products (such as interleukin (IL)-1 $\beta$ and tumor necrosis factor-a (TNFa)) into naive animals, can induce symptoms of neuropathic pain. ${ }^{17-19}$

The downstream effects of enhanced glial reactivity are strengthened by the fact that immune mediators, including those released by glia, are substantially more potent in modulating neuronal signaling compared with classical neurotransmitters on a per molecule basis. ${ }^{11}$ Glial proliferation, morphological changes and increases in protein expression can persist for months after initial injury, even beyond tissue healing. ${ }^{20,21}$ Moreover, proinflammatory mediators and glial-derived neurotransmitters can reciprocally stimulate glia in an autocrine and paracrine manner, thereby amplifying a positive feedback loop of unfavorable activity. $22-24$

How do glia become activated?

Glia function as a product of their microenvironment, and as such the types of receptors they express vary from site to site, and many receptors can be upregulated to make glia more 'tuned' to ongoing stimulation. Within the spinal cord, microglia are sensitive to ATP that binds to ionotropic (for example, P2X4 and P2X7) and metabotropic (for example, $\mathrm{P} 2 \mathrm{Y} 6$ and $\mathrm{P} 2 \mathrm{Y} 12$ ) purinergic receptors. $^{25-28}$ Chemokine receptors, such as CX3CR1 (with CX3CL1/fractalkine as ligand) and CCR2 (activated by CCL2/ MCP-1), also contribute to the microglial proinflammatory response, ${ }^{29-32}$ as well as receptors for the sensory neuropeptide, calcitonin gene-related peptide (CGRP) ${ }^{33}$ and interferons (IFN), such as IFNy. ${ }^{34}$ Akin to microglia, astrocytes can respond to ATP via the surface expression of P2X7 (refs 35,36) and P2Y1 (refs 25,37) and can be stimulated by IFN ${ }^{38}{ }^{38} \mathrm{CGRP}^{39-41}$ and several mediators released by microglia themselves, including TNFa and IL-18 (for reviews, see refs 11,42 ). There is also evidence that astrocytes express tachykinergic NK1 receptors, ${ }^{43}$ with substance $P$ potentiating the IL-1 $\beta$-mediated induction of IL-1 $\beta$ and prostaglandin E2 (PGE2) secretion from spinal cord astrocytes. ${ }^{44}$

Furthermore, a receptor family expressed by both glial cell types that has gained much recent attention, with regard to pain and immunity, are the Toll-like receptors (TLRs). ${ }^{45}$ TLRs allow glia to sense the presence of pathogen- or microbial-associated molecular products. Importantly, some receptor subtypes, such as TLR4, can additionally recognize endogenous 'self' warning molecules. Numerous putative ligands have been identified for these socalled damage-associated molecular patterns in the processing of pain, including high mobility group box 1 protein, ${ }^{46-48}$ heat-shock protein 90 (ref 49) and fibronectin. ${ }^{50}$

What proinflammatory products do glia release upon activation? Glial-induced upregulation of proinflammatory signaling is achieved through the induction of gene expression by numerous second messenger-mediated pathways. This includes activation of transcription by phosphorylation of mitogen-activated protein kinases and nuclear factor-KB. Specifically, the mitogen-activated protein kinases implicated here are p38 in microglia, ${ }^{51} \mathrm{c}$-Jun $\mathrm{N}$-terminal kinase in astrocytes ${ }^{52}$ and extracellular signal-regulated kinases (ERKs) in both glial cell types. ${ }^{53,54}$ The proinflammatory products subsequently released from microglia include IL-1 $\beta$, IL-6, IL-18, TNFa, PGE2, nitric oxide and brain-derived neurotrophic factor, and IL-1 $\beta$, IL-6, TNFa, IFN $\gamma$, CCL2, CXCL1, CXCL21 and MMP9 from astrocytes (for reviews, see refs 55-58). In addition, astrocytes can increase their release of gliotransmitters, such as ATP, ${ }^{59}$ glutamate and D-serine. ${ }^{60}$ 


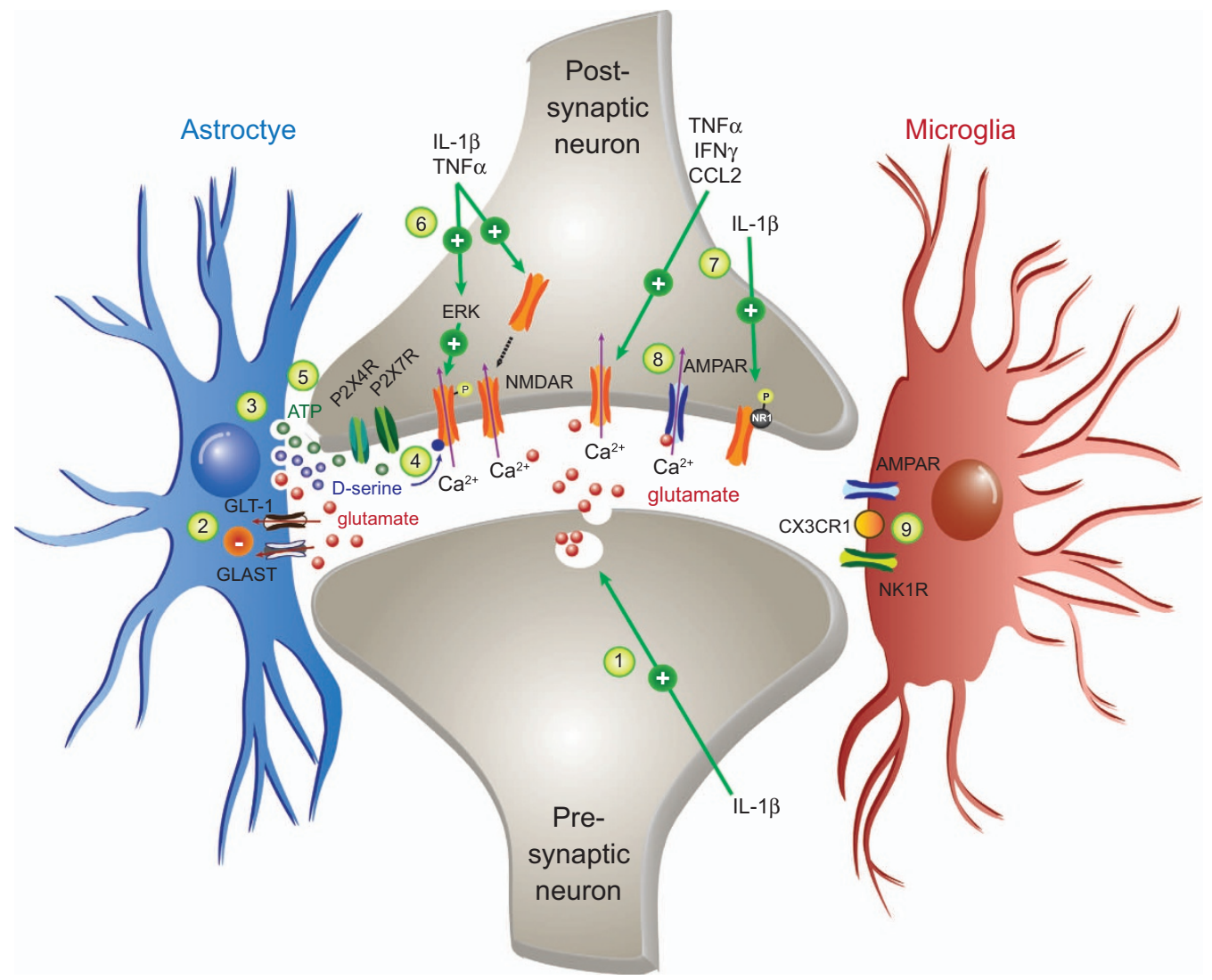

Figure 1. Schematic representation of the major proinflammatory glial-mediated alterations to excitatory synapses within the spinal dorsal horn that contribute to central sensitization. Strong or long-term noxious activation of astrocytes and microglia within the spinal dorsal horn can lead to the aberrant synthesis and release of proinflammatory mediators, such as TNF $\alpha$ and IL-1 $\beta$. The overarching effect of these neurokine signals in excitatory synapses contributes to central sensitization and facilitates the transmission of nociceptive signals to the brain. Some of the major known adaptations include the following. (1) Increased release of the excitatory neurotransmitter, glutamate, from presynaptic nerve terminals. (2) Suppression of astrocytic glutamate reuptake via downregulation of GLT-1 and GLAST activity. (3) Release of the glutamate from astrocytes, which is capable of increasing the excitability of nearby neurons. (4) D-serine, also released from astrocytes, enhances $\mathrm{Ca}^{2+}$ influx via binding to glycine sites on NMDA receptors on postsynaptic neurons. (5) Astrocytic release of ATP also increases postsynaptic excitability via activation of ligand-gated purinergic receptors, P2X4R and P2X7R. (6) TNF $\alpha$ and IL-1 $\beta$ increase translocation of NMDA receptors to the postsynaptic membrane and increases their conductance via an ERK-dependent pathway. (7) IL-1 $\beta$, TNF $\alpha$, IFN $\gamma$ and CCL2 increase NMDA receptor-mediated excitatory signaling; in the case of IL-1 $\beta$, this is thought to involve the phosphorylation of receptor subunits including NR1, 2a and 2b. (8) Proinflammatory cytokines have been linked to increased expression and activation of AMPA receptors at excitatory synapses. (9) Reactive microglia have increased expression of receptors for various neurotransmitters and chemokines (for example, AMPARs, NK1Rs and CX3CR1), which can induce the further release of proinflammatory cytokines upon stimulation, thereby perpetuating neuronal excitation. ERK, extracellular signal-regulated kinase; IFN, interferon; IL, interleukin; TNF $\alpha$, tumor necrosis factor- $\alpha$.

As the discovery of neuroimmune contributions to pain more than two decades ago, ${ }^{61-63}$ knowledge of glial-mediated molecular alterations in central sensitization has grown exponentially. Overall, their proinflammatory effects enhance excitatory tone and synaptic efficiency, thereby facilitating an exaggerated pain state. The sequelae of mediators released and resultant outcome are now realized to be highly dependent on the type of glial cell that is activated, the degree of its reactivity and the nature of the stimulus. ${ }^{64,65}$ For this reason, we will provide a brief summary of the major known excitatory and inhibitory adaptations, and strongly encourage readers to explore other excellent in-depth reviews. $11,14,15,42,66,67$

\section{GLIA ENHANCE EXCITATORY NOCICEPTIVE SIGNALING}

Glial-derived proinflammatory mediators enhance nociceptive signaling in the spinal cord first by facilitating glutamatergic neurotransmission (Figure 1). IL-1 $\beta$ has been shown to increase presynaptic release of glutamate, ${ }^{68}$ and IL-1 $\beta$, TNFa, CCL2 and IFNY increase postsynaptic N-methyl-D-aspartic (NMDA) and AMPA receptor currents. ${ }^{69-74}$ Postsynaptic neurons may further be excited by the release of glutamate from reactive astrocytes. ${ }^{75,76}$ TNFa can increase postsynaptic NMDA and AMPA-mediated activity by trafficking more receptor to the cell surface, ${ }^{77}$ and by increasing subsequent $\mathrm{Ca}^{2+}$ conductance through phosphorylation of neuronal ERK. ${ }^{78}$ In addition, IL-1 $\beta$ can induce SRC-1mediated phosphorylation of the NR1 subunit on NMDA. ${ }^{79,80}$ D-serine, a powerful neuromodulator released by reactive astrocytes, enhances depolarizing NMDA cation currents by binding to the NMDAR glycine site. ${ }^{81}$ There is also a persistent decrease in astrocytic expression of GLAST and GLT-1; ${ }^{82,83}$ loss of function of these glutamate transporters causes an elevation in extracellular glutamate concentrations within the synapse. ${ }^{84,85}$ Thus, the resultant aberrant uptake and/or release of glutamate, as well as the enhanced activity of its postsynaptic receptors, can contribute to excessive nociceptive signaling reaching the brain.

In addition, increased exocytosis of ATP from reactive astrocytes ${ }^{42}$ can directly stimulate neuronal excitation ${ }^{86}$ or induce glutamate release from presynaptic neurons, ${ }^{87}$ an effect that is facilitated by the upregulation of purinoceptors, such as 


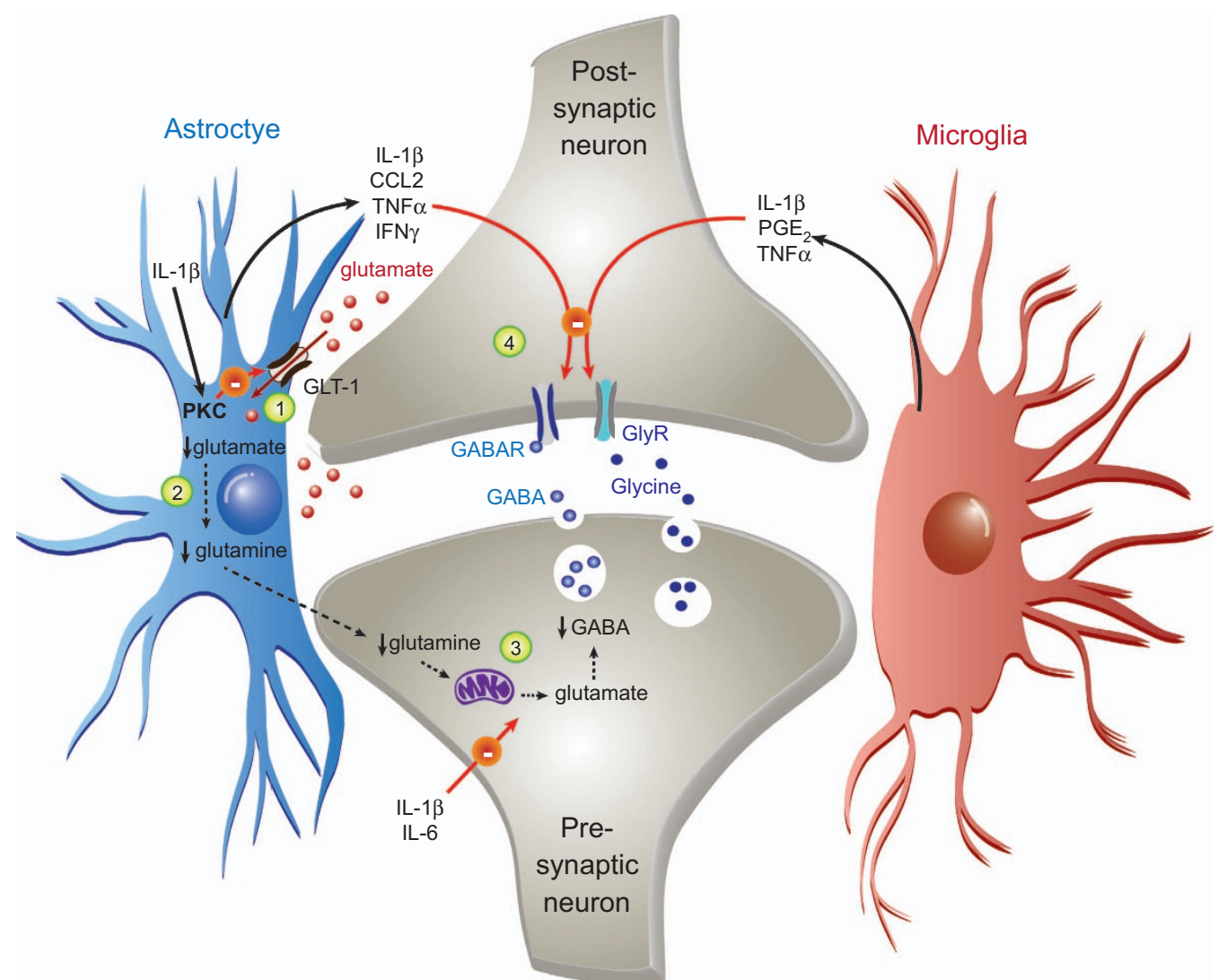

Figure 2. Schematic depicting the major proinflammatory glial-mediated changes to inhibitory synapses within the spinal dorsal horn that facilitate central sensitization. As mentioned in Figure 1, prolonged stimulation of astrocytes and microglia can lead to the increased synthesis and release of various proinflammatory cytokines and chemokines. Within inhibitory synapses of the spinal cord dorsal horn, the effects of these mediators ultimately lead to a reduction in inhibitory neurotransmission ('disinhibition'), which further facilitates central sensitization. For example: (1) IL-1 $\beta$ can mediate a decrease in the astrocytic uptake of glutamate, via a PKC-mediated suppression of glutamate transporter GLT-1. (2) The reduced uptake of glutamate via GLT-1 leads to decreased availability of glutamine for GABA synthesis. (3) IL-1 $\beta$ and IL-6 inhibit presynaptic GABA and glycine currents. (4) Last, IL-1 $\beta$, PGE2, CCL2, TNF $\alpha$ and IFN $\gamma$ decrease GABA and glycine receptor activity; in the case of IL-1 $\beta$, this is thought to be mediated via a PKC-dependent pathway. IFN, interferon; IL, interleukin; PKC, protein kinase C; TNF $\alpha$, tumor necrosis factor- $\alpha$.

$\mathrm{P} 2 \mathrm{X} 4 \mathrm{R}^{50,88} \mathrm{P} 2 \mathrm{X} 7 \mathrm{R}^{89,90}$ and P2Y12R. ${ }^{91,92}$ Levels of other cytokine and chemokine receptors are also upregulated, including IL-6induced microglial CX3CR1 (refs 29,93) that enhances pain via $\mathrm{IL}-1 \beta .^{94}$ Under certain conditions, such as IL-1 $\beta$ stimulation, both glial cell types may increase NK1-receptor expression. ${ }^{95}$ This potentiates the response to substance $\mathrm{P}_{1}^{43}$ in turn facilitating the release of astrocytic ATP ${ }^{59}$ and proinflammatory cytokines, including TNFa, IL-6 and PGE2. ${ }^{44,96,97}$ Last, TNFa, IL-1 $\beta$ and IL-6 can elicit long-term synaptic plasticity by inducing the phosphorylation of the transcription factor CAMP response element-binding protein $(\mathrm{CREB}){ }^{70}$ which may lead to the CREB-mediated transcription of COX-2 and NK1..$^{98-100}$

\section{GLIA ATTENUATE THE INHIBITION OF NOCICEPTIVE SIGNALING}

Heightened glial activation can also induce disinhibition; that is, a loss of inhibitory signals within the CNS that usually suppress nociceptive transmission, such as GABA and glycine signaling (Figure 2). The activation of microglial TLR4 by lipopolysaccharide (LPS) in rodent spinal slices induces IL-1 $\beta$ release, which suppresses postsynaptic GABA receptor function through the activation of protein kinase $C .{ }^{101}$ IL-1 $\beta$-induced protein kinase $C$ activation also attenuates astrocytic GLT-1 activity, leading to increased glutamate within the synaptic cleft. ${ }^{101}$ This not only drives a sustained excitation of postsynaptic neurons, but also a deficiency in the supply of glutamine, which is metabolized from glutamate following its reuptake. Consequently, glutamateglutamine cycle-dependent GABA synthesis by the presynaptic neuron is attenuated. ${ }^{102}$ Moreover, TNFa can prevent action potentials in inhibitory presynaptic neurons; ${ }^{103} \mathrm{IL}-1 \beta$ and IL-6 suppress presynaptic GABA and glycine currents; ${ }^{70}$ and PGE2, CCL2 and IFNy can attenuate postsynaptic electrical activity mediated by GABA or glycine. ${ }^{104-106}$ Thus, suppression of inhibitory influences within the spinal cord by glial-derived factors may exacerbate pain, by potentiating the transduction of nociceptive information.

\section{FEMALE SEX HORMONES AND NEURONAL HYPOTHESES UNDERLYING THE SEXUAL DIMORPHISM OF PAIN}

In addition to many pain syndromes having greater prevalence in females than males, other anecdotal evidence suggests that sex steroid hormones can have a direct influence on somatic and visceral persistent pain. In women, for instance, certain painful conditions typically occur during the menstrual years, and symptoms tend to fluctuate with the menstrual cycle. ${ }^{107,108}$ Symptom severity of several visceral pain conditions, such as irritable bowel syndrome, has been reported to decrease following menopause, ${ }^{109}$ and increase with hormone replacement therapy 
in postmenopausal women. ${ }^{110}$ Similarly, nociceptive stimuli in rodent visceral pain models are sensitive to both the changing steroid hormone levels throughout the estrous cycle, ${ }^{111-113}$ and during hormone supplementation following ovariectomy. ${ }^{114-116}$ Thus, it has been suggested that either elevated or fluctuating levels of sex hormones have a key role in exacerbating persistent pain. $^{117}$

However, the mechanisms underlying this modulation remain unclear and, to date, much of the research has focused on sex steroid-mediated alterations in neural activity and/or molecular targets expressed by neurons. For example, antagonism of neuronal NMDA receptors, often co-expressed with estrogen receptor a $(E R a)$, can attenuate the visceromotor reflex to colorectal distension with greater potency in untreated ovariectomized rats, compared with those with estradiol replacement. ${ }^{118}$ Colorectal distension is correlated with an increase in PKAmediated NMDAR NR1 subunit expression and phosphorylation in ovariectomized, estrogen-supplemented animals, compared with those not receiving estrogen. ${ }^{118}$ Furthermore, intrathecal administration of estrogen or an ERa-selective agonist can cause an increase in distension-evoked dorsal horn neuron pERK expression, and reverse the decrease in distension-evoked visceromotor reflex produced by ovariectomized rats. ${ }^{119}$

\section{DOES FEMALE SEX HORMONE MODULATION OF GLIAL REACTIVITY CONTRIBUTE TO THE FEMALE PREDOMINANCE OF PERSISTENT PAIN?}

Despite our understanding of the tetrapartite synapse in facilitating nociceptive signaling, it is likely that the contribution of glia has not yet received sufficient attention with regard to the female susceptibility to persistent pain. Intriguingly, TLRs - which, as discussed previously, are one receptor family expressed by glia and have an important role in the immunological response to pathogenic stimuli-are well situated to serve as an important molecular target for persistent pain conditions. This is particularly true for hormonally regulated female pain, as estrogen appears to influence TLR4-mediated proinflammation and pain in various conditions. For instance, glucuronide metabolites (which typically have a longer half-life than the parent molecule) of estrogen cause potent activation of TLR4 in vitro, correlating with enhanced mechanical allodynia in rats in vivo. ${ }^{120}$ The proinflammatory response to LPS is potentiated by estrogen in female but not male neonatal microglia. ${ }^{121}$ Moreover, although adult hippocampal microglia from ovariectomized rats in ex vivo preparations show a downregulation in LPS-induced inflammation upon estrogen supplementation, IL-1 $\beta$ mRNA is potentiated when estrogen is administered in vivo. ${ }^{121}$ Long-term estrogen exposure in ovariectomized mice promotes the expression of inflammatory mediators by CNS and peritoneal macrophages, in response to LPS activation in vivo ${ }^{122}$ and ex vivo, ${ }^{123}$ respectively. Intravenous administration of LPS in humans induces a similar decrease in visceral and musculoskeletal pain thresholds, although intriguingly a much more pronounced increase in circulating levels of plasma TNFa and IL- 6 was evidenced in females compared with males. ${ }^{124}$ A recent randomized control trial additionally showed that low-dose LPS was perceived to increase pain from suprathreshold noxious thermal stimuli in women only, and impaired conditioned pain modulation, a measure of endogenous pain inhibition. $^{125}$

Other studies have reported that TLR-mediated responses are important in male but not female pain. Using LPS-induced (in TLR4 mutant mice) ${ }^{126}$ and spinal nerve ligation (in TLR4 knockout mice $)^{127}$ models of pain enhancement, it was reported that mechanical allodynia is TLR4-dependent in males but TLR4independent in females. Inhibition of spinal p38 MAP kinase has been effective in attenuating inflammatory and neuropathic pain in male, but not female mice. ${ }^{128}$ It has further been proposed that female pain is independent of microglia in a rodent model of mechanical allodynia, alternatively involving the recruitment of T cells. ${ }^{129}$ However, this argument bears further consideration given that males are comparable to females in the generation of autoimmune T cells, but the phenotype of regulatory T cells (Treg), which serve to suppress inflammatory processes, may be more aggressive in males. ${ }^{130}$

Perhaps these opposing results mirror the highly complex, and well recognized, nature of estrogen being both a pronociceptive and antinociceptive hormone (see reviews in refs 131-135). Regardless, it is evident that the effects of female sex hormones on TLR4-mediated signaling are multifaceted and, given the range of receptors and pathways utilized by glia, highlight the need for research into neuroimmune mechanisms that may be specific to pain in females.

\section{SOMATIC VERSUS VISCERAL PAIN}

Persistent pain is a cardinal feature of chronic inflammation of peripheral tissues; thus, our increase in knowledge of neuroimmune signaling has led to investigations of the link between glia and persistent pain associated with inflammation. These data have been primarily acquired using animal models of neuropathic and somatic inflammatory pain, with considerably less attention given to pain arising from the viscera. Although there are many commonalities in the processing of somatic and visceral pain, there are also several important clinical distinctions (for reviews, see refs 136-138). For instance, pain cannot be evoked from all viscera; visceral pain is diffuse and poorly localized, owing to relatively few visceral afferents with extensive receptive fields; visceral pain can often be referred to remote locations, attributable to visceral and somatic afferent pathways converging into shared spinal levels; injury to the viscera does not necessarily cause pain; and intense motor and autonomic reflexes, such as nausea and muscle tension, usually accompany visceral pain. This aside, the fundamental mechanisms leading to the perception of somatic and visceral pain are similar, where enhanced activity from peripheral nociceptors activates ascending central pathways to the brain. Consequently, the involvement of neuroimmune signaling in persistent pain attributed to visceral inflammation has gained interest in the past few years. ${ }^{139}$

\section{NEUROIMMUNE CONTRIBUTIONS TO THE FEMALE PREDOMINANCE OF PAIN ASSOCIATED WITH INFLAMMATION OF THE PELVIC VISCERA}

The viscera are also where sex divergences in pain processing become particularly intriguing, owing to the unique organization of the reproductive and pelvic anatomy in males and females. It has been estimated that women are at greater risk of developing persistent pain within the pelvis, currently affecting between 15 and $24 \%$ of women ${ }^{140,141}$ (versus $1.8-12 \%$ in men ${ }^{142,143}$ ), including pain due to menstruation, intercourse, pregnancy and childbirth, and infection and inflammation via the vagina, cervix and uterus. ${ }^{3,144,145}$ Spinal microglia been found to contribute to pain in male animals with chronic prostatitis. ${ }^{146,147}$ To our knowledge, however, there are currently no comprehensive studies investigating glial contributions to pain associated with visceral diseases that have been restricted to, or with a substantial focus on, females. This alternative scope in research could reveal distinct female pain mechanisms that may be exploited to improve pain management.

Potential neuroimmune contributions to three visceral conditions that have a greater prevalence in, or are exclusive to, females are discussed below: inflammatory bowel disease (IBD), painful bladder syndrome and endometriosis. These pathologies share several features of neuropathic pain and somatic inflammation, such as heightened neural activity, decreased pain thresholds and increased pain behavior, indicating that central neuroimmune 
adaptations are probably taking place. This is supported by evidence demonstrating that experimentally induced IBD, cystitis or endometriosis can result in the sensitization of adjacent pelvic organs (for example, intestines, bladder and uterus). ${ }^{148-151}$ A similar phenomenon is observed clinically with the clustering of comorbidities in women with pelvic pain, such as patients with irritable bowel often presenting with viscerovisceral (for example, bladder or menstrual pain) or viscerosomatic (for example, pelvic muscle spasm, temporomandibular pain) complaints.

\section{Inflammatory bowel disease}

IBD comprises ulcerative colitis and Crohn's disease, both of which involve colonic inflammation; however, each has distinctive pathologic features. ${ }^{152}$ Although the prevalence of ulcerative colitis in males and females is generally similar, the female-male ratio of Crohn's disease in adults is increased up to approximately 1.2-1.3 times. $^{153,154}$ The studies on glia and IBD have utilized rodent models of di- or trinitrobenzene sulfonic acid-induced colitis, and potential differences between the sexes have not been analyzed. ${ }^{155-158}$ Nonetheless, marked increases in reactivity were described for microglia in the spinal cord and hippocampus, 155,156 and activated satellite glia in the dorsal root ganglia. ${ }^{156}$ This is associated with an upregulation of TNFa levels, ${ }^{155,156}$ and closer apposition between satellite glial cells and primary afferent neurons in the dorsal root ganglia ${ }^{156}$ via enhanced neuron-glia gap junction coupling. ${ }^{158}$ Associated centrally derived hyperalgesia was assessed by various methods, including increased visceromotor reflex activity ${ }^{156}$ and abdominal withdrawal reflex, ${ }^{157}$ to graded colonic distension. Intracerebroventricular, ${ }^{155}$ intrathecal or systemic ${ }^{156}$ minocycline or intrathecal administration of an anti-TNFa antibody ${ }^{157}$ attenuated the respective pain behaviors examined.

\section{Painful bladder syndrome}

Contributions of neuroimmune overactivity to persistent pain have also been suggested in animal models of, and human patients with, painful bladder syndrome. Formally known as interstitial cystitis, painful bladder syndrome affects approximately $3-7 \%$ of adult females and $2-4 \%$ of males, encompassing a range of bladder disorders that involve persistent pelvic pain or discomfort, nonspecific urinary symptoms and often cystitis. ${ }^{142,159,160}$ In a preliminary study using pooled data from male and female cats with spontaneous feline interstitial cystitis, the fluorescent intensity and number of GFAP-immunopositive astrocytes in the S1 spinal cord dorsal horn was increased compared with healthy unaffected cats. ${ }^{161}$ In addition, it has recently been demonstrated that peripheral blood mononuclear cells from women with painful bladder have an increased proinflammatory response to TLR2 and TLR4 stimulation in vitro. ${ }^{162}$ The magnitude of the proinflammatory response also positively correlated with the extent of pelvic and extra-pelvic pain, and the manifestation of comorbid conditions. ${ }^{163}$ This observation has great importance, as the TLR responsivity of peripheral blood mononuclear cells could serve as a neuroimmune biomarker for persistent pain, ${ }^{164}$ given the functional similarities between TLR signaling of immune cells in the periphery and in the CNS. Thus, the heightened TLR responsivity of peripheral immune cells in females with painful bladder syndrome may indicate that CNS sensitization involving neuroimmune modulation may be occurring in parallel, and remains to be explored further.

\section{Endometriosis}

Endometriosis is an estrogen-dependent, chronic, inflammatory medical condition in women, defined as the presence of endometrial tissue in extra-uterine locations, and commonly associated with painful pelvic symptoms. It affects an estimated $5-10 \%$ women of reproductive age, ${ }^{165}$ and up to $60 \%$ women with persistent pelvic pain. ${ }^{166}$ Endometriosis-associated pain is thought to solely arise from the presence of lesions, yet pain symptoms attributed to the disease can occur in women with lesions removed, ${ }^{167}$ and the severity of experienced pain correlates poorly with the degree of lesions. ${ }^{168,169}$ Thus, it exemplifies all that is female, from the unique visceral anatomy to the complex hormonal interplay, and the long-standing association with unexplained persistent pain.

Given that the conditions mentioned above affect the visceral organs present in both sexes, studying endometriosis (and indeed other female-specific conditions, such as vulvodynia) may provide further insight into subpopulation adaptations of neuroimmunemediated pain. Neural changes have been studied in detail, ${ }^{170,171}$ and it has been suggested that pain attributed to endometriosis is likely to involve neuronal processes leading to central sensitization. ${ }^{115,170,172,173}$ However, a potential role for glia has yet to be investigated. Accumulating evidence nevertheless demonstrates that there are alterations in peripheral immune function in endometriosis patients. ${ }^{174,175}$ LPS-stimulated peritoneal macrophages from women with endometriosis secrete significantly higher levels of proinflammatory cytokines (for example, IL-6 and TNFa) than non-diseased counterparts, an effect that can be attenuated by pre-treatment with a TLR4neutralizing antibody. ${ }^{176}$ TLR4 mRNA transcript expression is increased up to sixfold in endometriosis lesions compared with eutopic endometrium, ${ }^{177}$ and TLR2 and TLR9 mRNA from peritoneal effusions are upregulated in endometriosis patients compared with healthy controls. ${ }^{178}$ It remains to be determined whether the increased TLR levels are owing to an upregulation of the receptors per immune cell, or recruitment of TLR-bearing cells to the diseased area. There is now also solid evidence from multiple lines of investigation that the development and maintenance of endometriosis involves atypical peritoneal macrophage activity. ${ }^{179,180}$

Collectively, these data suggest that several alterations in neural, immune and neuroimmune functions exist in the femalepredominant conditions of IBS, painful bladder and endometriosis. Studies that further investigate visceral disease-associated modifications in neuroimmune signaling are desirable. Such information would further our knowledge of persistent pain mechanisms, and may also identify a molecular basis of pain susceptibility in the subpopulation of females.

\section{DOES THE DORSAL ROOT REFLEX AND NEUROGENIC INFLAMMATION CONTRIBUTE TO THE DEVELOPMENT OF VISCERAL INFLAMMATORY CONDITIONS?}

Besides painful symptoms, many chronic inflammatory diseases present with visible tissue abnormalities and consequently a vast number of studies focus on characterizing and treating these lesions. However, attention has recently shifted to unraveling the complex molecular pathways that instead underlie disease etiology. This is particularly interesting in the example of endometriosis, which is generally attributed to the movement of menstrual debris through the fallopian tubes into the abdominopelvic cavity during menses (retrograde menstruation). ${ }^{181}$ Although it is estimated that approximately $90 \%$ women aged 15-49 years will exhibit retrograde menstruation, ${ }^{182}$ only around one in ten will develop endometriosis lesions. Similarly, in many patients, the onset of IBD follows a bout of gastroenteritis, ${ }^{183}$ yet not all individuals with gastroenteritis will develop IBD. Thus it seems other factors affect the likelihood of disease formation in subsets of patients, leaving them susceptible to developing disease compared with their peers.

It is well established that sensitized sensory nerves can initiate or exacerbate inflammatory conditions by the release of 
neuropeptides from peripheral nerve terminals, such as CGRP and substance $P .^{184-186}$ This results in edema, immune cell infiltrate and other sequelae reminiscent of inflammation; hence has been termed neurogenic inflammation. ${ }^{187}$ The release of such peptides in the periphery is known to occur via two antidromic signaling mechanisms. Initially, there is strong local stimulation of peripheral nerve terminals at the site of disease, known as the 'axonal reflex'. With increased afferent input, the central terminals of sensory neurons within the spinal dorsal horn may also be excited, leading to anterograde propagation of action potentials back to the periphery (the 'dorsal root reflex'). ${ }^{188-190}$

Centrally derived neurogenic inflammation via the dorsal root reflex contributes to pathology in several animal models of peripheral inflammation, mostly involving the skin ${ }^{191-196}$ and joints, ${ }^{197-199}$ but also colitis. ${ }^{200}$ Compared with control animals receiving infused saline, colonic tissues from rats stimulated with intrathecal SP to the lumbar spine showed increased protein expression of the proinflammatory cytokine, migration inhibitory factor, mucosal edema and lymphocyte infiltration, effects that were attenuated by intrathecal pre-treatment with an NK1receptor antagonist. The efferent propagation of inflammation via central dorsal horn activation has also been supported in humans, by observations that relapses in ulcerative colitis have been associated with electrical stimulation of the spinal cord. $^{201-203}$

\section{DOES CENTRAL GLIAL STIMULATION AND OVERACTIVITY TRIGGER PERIPHERAL NEUROGENIC INFLAMMATION OF THE VISCERA?}

In addition to neuropeptides, it has been suggested that proinflammatory cytokines are able to stimulate dorsal horn afferents to influence the development of peripheral inflammation. ${ }^{204,205} \mathrm{It}$ has been reported that spinal IL-1 $\beta$, associated with reactive astrocytes, can contribute to the induction and maintenance of temporomandibular arthritis and associated pain. ${ }^{205}$ In these experiments, central disruption or inhibition of spinal IL-1 receptor type 1 (a receptor for IL-1 3 ) signaling in mice with established arthritis, resulted in significant attenuation of joint pathology. Mice without previously established arthritis showed an upregulation of astrocyte reactivity within the dorsal horn following local spinal overexpression of IL-1 $\beta$, as well as joint changes indicative of the initial stages of arthritic disease. Enhanced CGRP expression was observed in primary sensory fibers of mice with

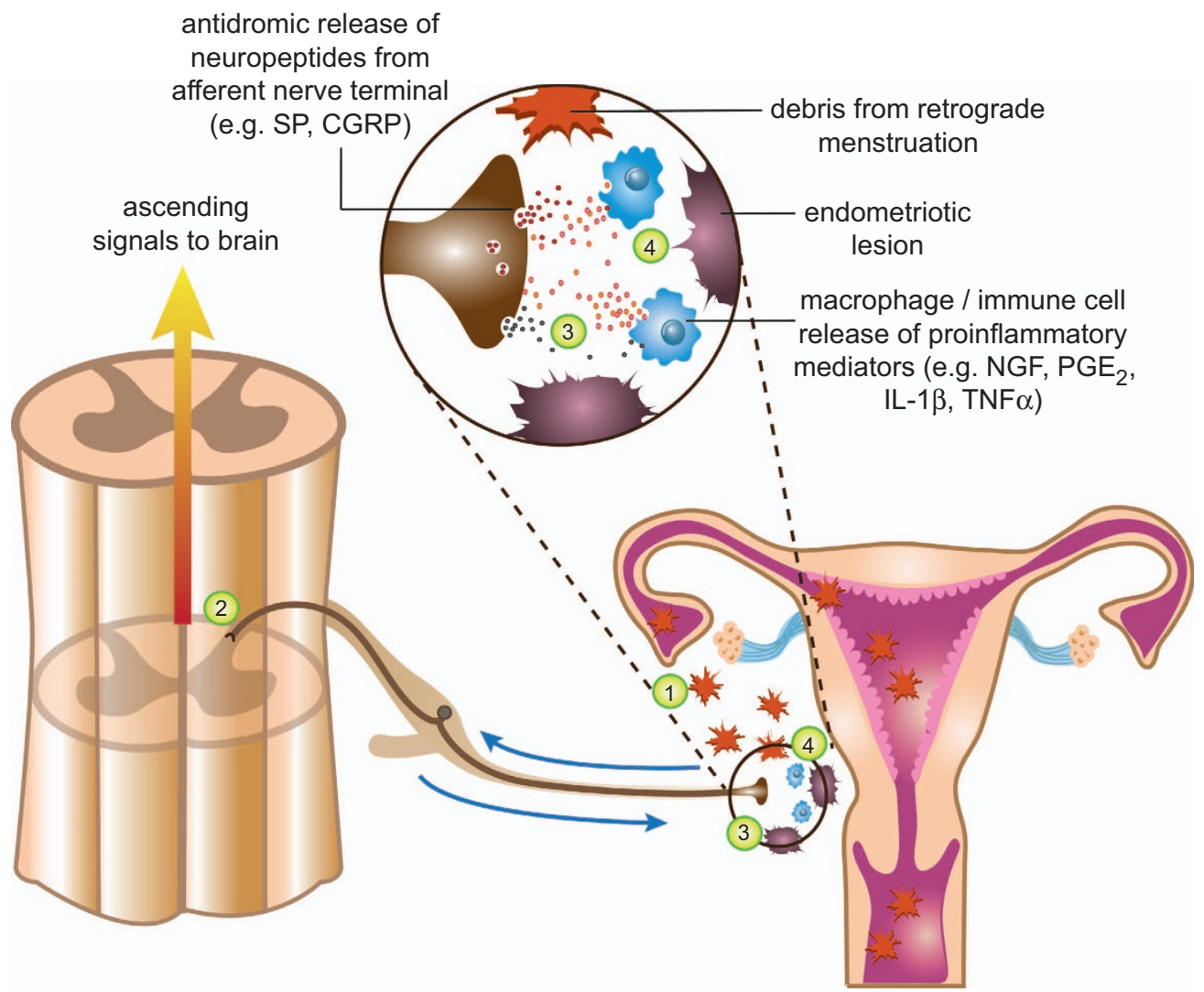

Figure 3. Possible involvement of centrally mediated neurogenic inflammation in the development of visceral inflammatory disease in the periphery: example for endometriosis. (1) During menstruation, endometrial debris passes both per vaginum and in a retrograde fashion through the fallopian tubes to the peritoneal cavity. (2) In certain women, the inflammatory events initiated by ectopic endometrial tissue activate sensory afferents innervating adjacent visceral structures, which transmit the noxious information to the spinal dorsal horn. In addition to exciting ascending neural signals projecting to the brain, afferent neurotransmitter release could potentially also activate spinal astrocytes and microglia, whose proinflammatory products contribute to the development of central sensitization and exaggerated pain (see Figures 1 and 2 for details). (3) Strong ongoing afferent stimulation associated with regular monthly menstruation and dysmenorrhea, as well as the excitatory environment created by reactive glia, may reciprocally activate the central terminals of sensory nerves. This can then induce the antidromic release of neuropeptides (such as SP and CGRP) at the peripheral site of disease (the 'dorsal root reflex'). (4) The subsequent induction of neurogenic inflammation, including the release of cytokines (IL-1 $\beta$ and TNF $\alpha$ ), PGE2 and nerve growth factor (NGF) from local immune cells, may then contribute to an environment that encourages the implantation of endometrial debris onto the peritoneum, and the development of endometriotic lesions (including the associated neovascularization and sprouted innervation). CGRP, calcitonin gene-related peptide; IL, interleukin; PGE2, prostaglandin E2; TNF $\alpha$, tumor necrosis factor- $\alpha$. 
IL-1 $\beta$-overexpression (peripheral projections, dorsal root ganglia and central projections), which also displayed spontaneous behavior indicative of pain. It was suggested that bidirectional crosstalk between the CNS and peripheral joints, via spinal IL-1 $\beta$ stimulation of sensory afferents to release CGRP in the periphery, may have a role in the exacerbation of inflammation and pain. ${ }^{205}$ Therefore, heightened spinal glial reactivity and proinflammatory signaling may contribute to ongoing peripheral inflammation, as well as enhancing pain by central sensitization.

This raises the interesting question as to whether centrally derived neurogenic inflammation, generated in part by neuroimmune signaling, contributes to the perpetuation of other inflammatory diseases. Indeed, neurogenic inflammatory processes have been implicated in the exacerbation of IBD, cystitis and endometriosis. ${ }^{206-209}$ In endometriosis, neurogenic inflammation is thought to create an optimal peritoneal environment for ectopic lesion formation in the visceral tissues. ${ }^{210,211}$ In this setting, enhanced afferent signaling in response to accumulating endometrial debris may facilitate lesion development by a positive feedback loop (Figure 3). Further research into the role of glia and the dorsal root reflex in the development of inflammation are recommended.

\section{EARLY-LIFE STRESSORS AS CENTRAL GLIAL PRIMERS FOR VISCERAL INFLAMMATION}

It is now realized that glia have the ability to be 'primed' by prior experience to over-respond to new immune challenges (a 'two-hit hypothesis $\left.{ }^{\prime 14}\right)$. This is shown where laparotomy and intraperitoneal injection of LPS each individually cause modest increases in mechanical allodynia. However, allodynia is potentiated up to threefold when laparotomy and LPS are administered sequentially, with enhanced pain being associated with heightened microglial reactivity. ${ }^{212}$

Many studies are currently investigating the impact of early-life stressors, such as maternal separation or injury, on long-lasting glial alterations in the adult. Such events can be the 'first hit' that primes glia to over-respond and be detrimental in restoring 'second hit' immune challenges later in life. Visceral hyperalgesia can be enhanced by early adverse events, ${ }^{213-216}$ although associations with glia have thus far been described only for somatic pain. For instance, incisional surgery of the neonatal rat hind paw caused an increase in the intensity of microglial activation and expression within the dorsal horn that persisted into adulthood..$^{20}$ This was associated with hyperalgesia following incisional surgery as an adult, and was prevented by intrathecal administration of minocycline at the time of adult injury. Thus, this suggests that early adverse life events provoking long-term heightened glial reactivity may lead to greater sensitivity to future harmful stimuli.

Priming of spinal glia may provide an explanation for why some subpopulations, such as females, are predisposed to developing certain painful conditions. If the neuroimmune communication has been primed before a persistent pain-triggering insult, then this mechanism may inherently increase disease burden in females (or males) due to the increased release of proinflammatory products, and may also be exacerbated by the activity of sex hormones, such as estradiol. Early aggravation of spinal glia might therefore contribute to the development of peripheral inflammation, via the dorsal root reflex or otherwise. Regarding endometriosis, clinical records from female monkeys have indicated that animals exposed to prior adverse life events, such as laparoscopic examination and cesarean section, were associated with an increase in the incidence of developing endometriosis. ${ }^{217,218}$ The initial scenario of gastroenteritis preceding IBD could further represent the 'first hit' of irritation that sensitizes the neuroimmune system, later contributing to disease progression. Direct evidence linking early-life glial priming and the incidence of visceral inflammation in adulthood await to be studied.

\section{BEYOND 'HYSTERIA' TOWARDS TARGETED TREATMENT OF FEMALE PAIN}

Our current understanding of central sensitization leading to the development of persistent pain involves interactions between neurons and highly reactive glia. Studying alterations in these neuroimmune connections under various conditions provides enormous potential for meaningful new research discoveries and, given the significant female predominance of pain, may contribute to understanding the biological mechanisms that underlie sex differences in pain processes. Using both male and female subjects will be crucial for this future pain research. Exploring painful conditions of the viscera that are most prevalent or specific to each of the sexes, such as IBD, painful bladder syndrome and endometriosis in females and prostatitis in males, may additionally provide clues into the unique anatomical and neuroendocrine influences on pain sensitivity. Indeed, the potential contribution of neuroimmune and neurogenic signaling to inflammation and pain is a novel avenue for gynecological and urogenital research. Although much of this review has focused on female sex hormones and pain, male sex hormones may also have a critical role, where low testosterone levels are an emerging link to persistent pain states in both the sexes. ${ }^{219,220}$ Thus, prospective studies comparing the root causes of sex-specific pain conditions may have important implications for both future pain prevention and treatment strategies.

As we unravel the molecular pathways involved in enhancing nociceptive transmission, this will provide opportunities for resultant drug discovery. New pharmacotherapies that aim to target glia to modulate their deleterious, proinflammatory contributions to pain are now steadily emerging. ${ }^{14,221}$ This is emphasized by recent exciting studies that have for the first time demonstrated an upregulation of central glial cell reactivity in pain patients in vivo. ${ }^{222-224}$ Although the translation of results from animals to humans has been variable in effectiveness, an issue plaguing the field of pain at large, ${ }^{225,226}$ it is likely that the future analgesic success of these agents will be highly dependent on the type of injury or disease, the selection of drug and dosing regimen, the route of delivery and the timing of treatment. With continued investigations, the neuroimmune system represents a key target to decrease the burden of persistent pain.

\section{CONFLICT OF INTEREST}

The authors declare no conflict of interest.

\section{ACKNOWLEDGMENTS}

We thank Mr Tavik Morgenstern for assistance with the generation of figures, and Emeritus Professor Roland Sussex for editorial review of the manuscript. This review was supported in part by funding from the University of Adelaide Joyner Scholarship in Medicine (to KND); the Pelvic Pain Foundation of Australia (SFE); a National Health and Medical Research Council CJ Martin Postdoctoral Fellowship (to PMG, ID: 1054091); a National Institutes of Health Grant (to LRW, ID: DE021966); and an Australian Research Council Fellowship (to MRH, ID: DP110100297).

\section{REFERENCES}

1 King H. Once upon a text: hysteria from Hippocrates. Hippocrates' Woman: Reading the female body in Ancient Greece, 1st edn. Routledge: London, UK, 1998, pp 205-246.

2 Freud S, Freud A. Observation of a severe case of hemi-anaesthesia in a hysterical male (1886) and Hysteria (1888). The Standard Edition of the Complete Psychological Works of Sigmund Freud: Pre-Psycho-Analytic and Unpublished Drafts. Vintage Classics: London, UK, 2001, pp 23-34, 39-47.

3 Berkley KJ. Sex differences in pain. Behav Brain Sci 1997; 20: 371-380. 
4 Greenspan JD, Craft RM, LeResche L, Arendt-Nielsen L, Berkley KJ, Fillingim RB et al. Studying sex and gender differences in pain and analgesia: a consensus report. Pain 2007; 132(Suppl 1): S26-S45.

5 Fillingim RB, King CD, Ribeiro-Dasilva MC, Rahim-Williams B, Riley JL. Sex, gender, and pain: a review of recent clinical and experimental findings. J Pain 2009; 10: 447-485.

6 Mogil JS. Sex differences in pain and pain inhibition: multiple explanations of a controversial phenomenon. Nat Rev Neurosci 2012; 13: 859-866.

7 Mogil JS, Chanda ML. The case for the inclusion of female subjects in basic science studies of pain. Pain 2005; 117: 1-5.

8 Merskey H, Bogduk N. Part III: Pain terms, a current list with definitions and notes on usage. Classification of Chronic Pain, 2nd edn. IASP Press: Seattle, WA, USA, 1994, pp 209-214.

9 Woolf CJ, Salter MW. Neuronal plasticity: increasing the gain in pain. Science 2000; 288: 1765-1769.

10 Campbell JN, Meyer RA. Mechanisms of neuropathic pain. Neuron 2006; 52 77-92.

11 Ji RR, Berta T, Nedergaard M. Glia and pain: is chronic pain a gliopathy? Pain 2013; 154(Suppl 1): S10-S28.

12 De Leo JA, Tawfik VL, LaCroix-Fralish ML. The tetrapartite synapse: path to CNS sensitization and chronic pain. Pain 2006; 122: 17-21.

13 Ren K, Dubner R. Activity-triggered tetrapartite neuron-glial interactions following peripheral injury. Curr Opin Pharmacol 2015; 26: 16-25.

14 Grace PM, Hutchinson MR, Maier SF, Watkins LR. Pathological pain and the neuroimmune interface. Nat Rev Immunol 2014; 14: 217-231.

15 Milligan ED, Watkins LR. Pathological and protective roles of glia in chronic pain. Nat Rev Neurosci 2009; 10: 23-36.

16 Maier SF, Watkins LR. Cytokines for psychologists: implications of bidirectional immune-to-brain communication for understanding behavior, mood, and cog nition. Psychol Rev 1998; 105: 83-107.

17 Tsuda M, Shigemoto-Mogami Y, Koizumi S, Mizokoshi A, Kohsaka S, Salter MW et al. P2X4 receptors induced in spinal microglia gate tactile allodynia after nerve injury. Nature 2003; 424: 778-783.

18 Coull JA, Beggs S, Boudreau D, Boivin D, Tsuda M, Inoue $K$ et al. BDNF from microglia causes the shift in neuronal anion gradient underlying neuropathic pain. Nature 2005; 438: 1017-1021.

19 Kawasaki Y, Xu ZZ, Wang X, Park JY, Zhuang ZY, Tan PH et al. Distinct roles of matrix metalloproteases in the early- and late-phase development of neuropathic pain. Nat Med 2008; 14: 331-336.

20 Beggs S, Currie G, Salter MW, Fitzgerald M, Walker SM. Priming of adult pain responses by neonatal pain experience: maintenance by central neuroimmune activity. Brain 2012; 135(Pt 2): 404-417.

21 Schwaller F, Beggs S, Walker SM. Targeting p38 mitogen-activated protein kinase to reduce the impact of neonatal microglial priming on incision-induced hyperalgesia in the adult rat. Anesthesiology 2015; 122: 1377-1390.

22 Shiga H, Tojima T, Ito E. Ca2+ signaling regulated by an ATP-dependent autocrine mechanism in astrocytes. Neuroreport 2001; 12: 2619-2622.

23 Anderson CM, Bergher JP, Swanson RA. ATP-induced ATP release from astrocytes. J Neurochem 2004; 88: 246-256.

24 Zhang X, Zeng L, Yu T, Xu Y, Pu S, Du D et al. Positive feedback loop of autocrine BDNF from microglia causes prolonged microglia activation. Cell Physiol Biochem 2014; 34: 715-723.

25 Kobayashi K, Fukuoka T, Yamanaka H, Dai Y, Obata K, Tokunaga A et al. Neurons and glial cells differentially express $\mathrm{P} 2 \mathrm{Y}$ receptor mRNAs in the rat dorsal root ganglion and spinal cord. J Comp Neurol 2006; 498: 443-454.

26 Inoue K. Purinergic systems in microglia. Cell Mol Life Sci 2008; 65: 3074-3080.

27 Morioka N, Tokuhara M, Harano S, Nakamura Y, Hisaoka-Nakashima K, Nakata Y The activation of P2Y6 receptor in cultured spinal microglia induces the production of CCL2 through the MAP kinases-NF-kappaB pathway. Neuropharmacology 2013; 75: 116-125.

28 Shieh CH, Heinrich A, Serchov T, van Calker D, Biber K. P2X7-dependent, but differentially regulated release of IL-6, CCL2, and TNF-alpha in cultured mouse microglia. Glia 2014; 62: 592-607.

29 Verge GM, Milligan ED, Maier SF, Watkins LR, Naeve GS, Foster AC. Fractalkine (CX3CL1) and fractalkine receptor (CX3CR1) distribution in spinal cord and dorsal root ganglia under basal and neuropathic pain conditions. Eur J Neurosci 2004; 20: $1150-1160$

30 Thacker MA, Clark AK, Bishop T, Grist J, Yip PK, Moon LD et al. CCL2 is a key mediator of microglia activation in neuropathic pain states. Eur J Pain 2009; 13: 263-272.

31 Toyomitsu E, Tsuda M, Yamashita T, Tozaki-Saitoh H, Tanaka Y, Inoue K. CCL2 promotes $\mathrm{P} 2 \mathrm{X} 4$ receptor trafficking to the cell surface of microglia. Purinergic Signal 2012; 8: 301-310.

$32 \mathrm{Hu}$ JH, Wu MY, Tao M, Yang JP. Changes in protein expression and distribution of spinal CCR2 in a rat model of bone cancer pain. Brain Res 2013; 1509: 1-7.
33 Nieto FR, Clark AK, Grist J, Chapman V, Malcangio M. Calcitonin gene-related peptide-expressing sensory neurons and spinal microglial reactivity contribute to pain states in collagen-induced arthritis. Arthritis Rheumatol 2015; 67: 1668-1677.

34 Tsuda M, Masuda T, Kitano J, Shimoyama H, Tozaki-Saitoh H, Inoue K. IFNgamma receptor signaling mediates spinal microglia activation driving neuropathic pain. Proc Natl Acad Sci USA 2009; 106: 8032-8037.

35 Duan S, Anderson CM, Keung EC, Chen Y, Chen Y, Swanson RA. P2X7 receptormediated release of excitatory amino acids from astrocytes. $J$ Neurosci 2003; 23: 1320-1328.

36 Narcisse L, Scemes E, Zhao Y, Lee SC, Brosnan CF. The cytokine IL-1beta transiently enhances P2X7 receptor expression and function in human astrocytes. Glia 2005; 49: 245-258.

37 Zeng JW, Liu XH, Zhang JH, Wu XG, Ruan HZ. P2Y1 receptor-mediated glutamate release from cultured dorsal spinal cord astrocytes. J Neurochem 2008; 106: 2106-2118.

38 Zhang FF, Morioka N, Nakashima-Hisaoka K, Nakata Y. Spinal astrocytes stimulated by tumor necrosis factor-alpha and/or interferon-gamma attenuate connexin 43-gap junction via c-jun terminal kinase activity. J Neurosci Res 2013; 91: 745-756.

39 Reddington M, Priller J, Treichel J, Haas C, Kreutzberg GW. Astrocytes and microglia as potential targets for calcitonin gene related peptide in the central nervous system. Can J Physiol Pharmacol 1995; 73: 1047-1049.

40 Cady RJ, Glenn JR, Smith KM, Durham PL. Calcitonin gene-related peptide promotes cellular changes in trigeminal neurons and glia implicated in peripheral and central sensitization. Mol Pain 2011; 7: 94.

41 Hansen RR, Vacca V, Pitcher T, Clark AK, Malcangio M. Role of extracellular calcitonin gene-related peptide in spinal cord mechanisms of cancer-induced bone pain. Pain 2015; 157: 666-676.

42 Hansen RR, Malcangio M. Astrocytes-multitaskers in chronic pain. Eur J Pharmacol 2013; 716: 120-128.

43 Miyano K, Morioka N, Sugimoto T, Shiraishi S, Uezono Y, Nakata Y. Activation of the neurokinin-1 receptor in rat spinal astrocytes induces $\mathrm{Ca} 2+$ release from IP3sensitive $\mathrm{Ca} 2+$ stores and extracellular Ca2+ influx through TRPC3. Neurochem Int 2010; 57: 923-934.

44 Palma C, Minghetti L, Astolfi M, Ambrosini E, Silberstein FC, Manzini S et al. Functional characterization of substance $P$ receptors on cultured human spinal cord astrocytes: synergism of substance $P$ with cytokines in inducing interleukin6 and prostaglandin E2 production. Glia 1997; 21: 183-193.

45 Nicotra L, Loram LC, Watkins LR, Hutchinson MR. Toll-like receptors in chronic pain. Exp Neurol 2012; 234: 316-329.

46 Tong W, Wang W, Huang J, Ren N, Wu SX, Li YQ. Spinal high-mobility group box 1 contributes to mechanical allodynia in a rat model of bone cancer pain. Biochem Biophys Res Commun 2010; 395: 572-576.

47 Ren PC, Zhang Y, Zhang XD, An LJ, Lv HG, He J et al. High-mobility group box 1 contributes to mechanical allodynia and spinal astrocytic activation in a mouse model of type 2 diabetes. Brain Res Bull 2012; 88: 332-337.

48 Agalave NM, Larsson M, Abdelmoaty S, Su J, Baharpoor A, Lundback P et al. Spinal HMGB1 induces TLR4-mediated long-lasting hypersensitivity and glial activation and regulates pain-like behavior in experimental arthritis. Pain 2014; 155: 1802-1813.

49 Hutchinson MR, Ramos KM, Loram LC, Wieseler J, Sholar PW, Kearney JJ et al. Evidence for a role of heat shock protein-90 in toll like receptor 4 mediated pain enhancement in rats. Neuroscience 2009; 164: 1821-1832.

50 Tsuda M, Toyomitsu E, Komatsu T, Masuda T, Kunifusa E, Nasu-Tada K et al. Fibronectin/integrin system is involved in P2X(4) receptor upregulation in the spinal cord and neuropathic pain after nerve injury. Glia 2008; 56: 579-585.

51 Svensson Cl, Marsala M, Westerlund A, Calcutt NA, Campana WM, Freshwater JD et al. Activation of p38 mitogen-activated protein kinase in spinal microglia is a critical link in inflammation-induced spinal pain processing. J Neurochem 2003. 86: 1534-1544.

52 Zhuang ZY, Wen YR, Zhang DR, Borsello T, Bonny C, Strichartz GR et al. A peptide c-Jun N-terminal kinase (JNK) inhibitor blocks mechanical allodynia after spinal nerve ligation: respective roles of JNK activation in primary sensory neurons and spinal astrocytes for neuropathic pain development and maintenance. $J$ Neurosci 2006; 26: 3551-3560

53 Zhuang ZY, Gerner P, Woolf CJ, Ji RR. ERK is sequentially activated in neurons, microglia, and astrocytes by spinal nerve ligation and contributes to mechanical allodynia in this neuropathic pain model. Pain 2005; 114: 149-159.

54 Wang LN, Yao M, Yang JP, Peng J, Peng Y, Li CF et al. Cancer-induced bone pain sequentially activates the ERK/MAPK pathway in different cell types in the rat spinal cord. Mol Pain 2011; 7: 48.

55 Old EA, Malcangio M. Chemokine mediated neuron-glia communication and aberrant signalling in neuropathic pain states. Curr Opin Pharmacol 2012; 12: 67-73. 
56 Clark AK, Old EA, Malcangio M. Neuropathic pain and cytokines: current perspectives. J Pain Res 2013; 6: 803-814.

57 Mika J, Zychowska M, Popiolek-Barczyk K, Rojewska E, Przewlocka B. Importance of glial activation in neuropathic pain. Eur J Pharmacol 2013; 716: 106-119.

58 Sofroniew MV. Multiple roles for astrocytes as effectors of cytokines and inflammatory mediators. Neuroscientist 2014; 20: 160-172.

59 Werry EL, Liu GJ, Bennett MR. Glutamate-stimulated ATP release from spinal cord astrocytes is potentiated by substance P. J Neurochem 2006; 99: 924-936.

60 Mothet JP, Pollegioni L, Ouanounou G, Martineau M, Fossier P, Baux G. Glutamate receptor activation triggers a calcium-dependent and SNARE proteindependent release of the gliotransmitter D-serine. Proc Natl Acad Sci USA 2005; 102: $5606-5611$.

61 Garrison CJ, Dougherty PM, Kajander KC, Carlton SM. Staining of glial fibrillary acidic protein (GFAP) in lumbar spinal cord increases following a sciatic nerve constriction injury. Brain Res 1991; 565: 1-7.

62 Garrison CJ, Dougherty PM, Carlton SM. GFAP expression in lumbar spinal cord of naive and neuropathic rats treated with MK-801. Exp Neurol 1994; 129: 237-243.

63 Meller ST, Dykstra C, Grzybycki D, Murphy S, Gebhart GF. The possible role of glia in nociceptive processing and hyperalgesia in the spinal cord of the rat. Neuropharmacology 1994; 33: 1471-1478.

64 Ransohoff RM, Perry VH. Microglial physiology: unique stimuli, specialized responses. Annu Rev Immunol 2009; 27: 119-145.

65 Kosek E, Altawil R, Kadetoff D, Finn A, Westman M, Le Maitre E et al. Evidence of different mediators of central inflammation in dysfunctional and inflammatory pain--interleukin-8 in fibromyalgia and interleukin-1 beta in rheumatoid arthritis. J Neuroimmunol 2015; 280: 49-55.

66 Gao YJ, Ji RR. Targeting astrocyte signaling for chronic pain. Neurotherapeutics 2010; 7: 482-493.

67 Taves S, Berta T, Chen G, Ji RR. Microglia and spinal cord synaptic plasticity in persistent pain. Neural Plast 2013; 2013: 753656.

68 Yan X, Weng HR. Endogenous interleukin-1 beta in neuropathic rats enhances glutamate release from the primary afferents in the spinal dorsal horn through coupling with presynaptic N-methyl-D-aspartic acid receptors. J Biol Chem 2013; 288: 30544-30557.

69 Vikman KS, Hill RH, Backstrom E, Robertson B, Kristensson K. Interferon-gamma induces characteristics of central sensitization in spinal dorsal horn neurons in vitro. Pain 2003; 106: 241-251.

70 Kawasaki Y, Zhang L, Cheng JK, Ji RR. Cytokine mechanisms of central sensitization: distinct and overlapping role of interleukin-1 beta, interleukin-6, and tumor necrosis factor-alpha in regulating synaptic and neuronal activity in the superficial spinal cord. J Neurosci 2008; 28: 5189-5194.

71 Gao YJ, Zhang L, Samad OA, Suter MR, Yasuhiko K, Xu ZZ et al. JNK-induced MCP-1 production in spinal cord astrocytes contributes to central sensitization and neuropathic pain. J Neurosci 2009; 29: 4096-4108.

72 Liu T, Jiang CY, Fujita T, Luo SW, Kumamoto E. Enhancement by interleukin1 beta of AMPA and NMDA receptor-mediated currents in adult rat spinal superficial dorsal horn neurons. Mol Pain 2013; 9: 16.

73 Clark AK, Gruber-Schoffnegger D, Drdla-Schutting R, Gerhold KJ, Malcangio M, Sandkuhler J. Selective activation of microglia facilitates synaptic strength. J Neurosci 2015; 35: 4552-4570.

74 Gruber-Schoffnegger D, Drdla-Schutting R, Hönigsperger C, Wunderbaldinger G, Gassner M, Sandkühler J. Induction of thermal hyperalgesia and synaptic longterm potentiation in the spinal cord lamina I by TNF- $\alpha$ and IL- $1 \beta$ is mediated by glial cells. J Neurosci 2013; 33: 6540-6551.

75 Jourdain P, Bergersen LH, Bhaukaurally K, Bezzi P, Santello M, Domercq M et al. Glutamate exocytosis from astrocytes controls synaptic strength. Nat Neurosci 2007; 10: 331-339.

76 Parpura V, Basarsky TA, Liu F, Jeftinija K, Jeftinija S, Haydon PG. Glutamatemediated astrocyte-neuron signalling. Nature 1994; 369: 744-747.

77 Choi Jl, Svensson Cl, Koehrn FJ, Bhuskute A, Sorkin LS. Peripheral inflammation induces tumor necrosis factor dependent AMPA receptor trafficking and Akt phosphorylation in spinal cord in addition to pain behavior. Pain 2010; 149: 243-253.

78 Xu ZZ, Zhang L, Liu T, Park JY, Berta T, Yang R et al. Resolvins RvE1 and RvD1 attenuate inflammatory pain via central and peripheral actions. Nat Med 2010; 16: 592-597, 1p following 597.

79 Viviani B, Bartesaghi S, Gardoni F, Vezzani A, Behrens MM, Bartfai T et al. Interleukin-1beta enhances NMDA receptor-mediated intracellular calcium increase through activation of the Src family of kinases. J Neurosci 2003; 23: 8692-8700.

80 Zhang RX, Li A, Liu B, Wang L, Ren K, Zhang H et al. IL-1 ra alleviates inflammatory hyperalgesia through preventing phosphorylation of NMDA receptor NR-1 subunit in rats. Pain 2008; 135: 232-239.
81 Lefevre Y, Amadio A, Vincent P, Descheemaeker A, Oliet SH, Dallel R et al. Neuropathic pain depends upon d-serine co-activation of spinal NMDA receptors in rats. Neurosci Lett 2015; 603: 42-47.

82 Sung B, Lim G, Mao J. Altered expression and uptake activity of spinal glutamate transporters after nerve injury contribute to the pathogenesis of neuropathic pain in rats. J Neurosci 2003; 23: 2899-2910.

83 Xin WJ, Weng HR, Dougherty PM. Plasticity in expression of the glutamate transporters GLT-1 and GLAST in spinal dorsal horn glial cells following partial sciatic nerve ligation. Mol Pain 2009; 5: 15.

84 Liaw WJ, Stephens RL Jr, Binns BC, Chu Y, Sepkuty JP, Johns RA et al. Spinal glutamate uptake is critical for maintaining normal sensory transmission in rat spinal cord. Pain 2005; 115: 60-70.

85 Weng HR, Chen JH, Cata JP. Inhibition of glutamate uptake in the spinal cord induces hyperalgesia and increased responses of spinal dorsal horn neurons to peripheral afferent stimulation. Neuroscience 2006; 138: 1351-1360.

86 Jahr CE, Jessell TM. ATP excites a subpopulation of rat dorsal horn neurones. Nature 1983; 304: 730-733.

87 Nakatsuka T, Gu JG. ATP P2X receptor-mediated enhancement of glutamate release and evoked EPSCs in dorsal horn neurons of the rat spinal cord. J Neurosci 2001; 21: 6522-6531.

88 Ulmann L, Hatcher JP, Hughes JP, Chaumont S, Green PJ, Conquet F et al. Upregulation of $\mathrm{P} 2 \mathrm{X} 4$ receptors in spinal microglia after peripheral nerve injury mediates BDNF release and neuropathic pain. J Neurosci 2008; 28: 11263-11268.

89 Kobayashi K, Takahashi E, Miyagawa Y, Yamanaka H, Noguchi K. Induction of the P2X7 receptor in spinal microglia in a neuropathic pain model. Neurosci Lett 2011; 504: 57-61.

90 Ying YL, Wei XH, Xu XB, She SZ, Zhou L, Lv J et al. Over-expression of P2X7 receptors in spinal glial cells contributes to the development of chronic postsurgical pain induced by skin/muscle incision and retraction (SMIR) in rats. Exp Neurol 2014; 261: 836-843.

91 Tozaki-Saitoh H, Tsuda M, Miyata H, Ueda K, Kohsaka S, Inoue K. P2Y12 receptors in spinal microglia are required for neuropathic pain after peripheral nerve injury. J Neurosci 2008; 28: 4949-4956.

92 Kobayashi K, Yamanaka H, Fukuoka T, Dai Y, Obata K, Noguchi K. P2Y12 receptor upregulation in activated microglia is a gateway of p38 signaling and neuropathic pain. J Neurosci 2008; 28: 2892-2902.

93 Lee K-M, Jeon S-M, Cho H-J. Interleukin-6 induces microglial CX3CR1 expression in the spinal cord after peripheral nerve injury through the activation of p38 MAPK. Eur J Pain 2010; 14: 682.e1-682.e12.

94 Willemen $\mathrm{HL}$, Eijkelkamp N, Wang H, Dantzer R, Dorn GW 2nd, Kelley KW et al. Microglial/macrophage GRK2 determines duration of peripheral IL-1betainduced hyperalgesia: contribution of spinal cord CX3CR1, p38 and IL-1 signaling. Pain 2010; 150: 550-560.

95 Guo CJ, Douglas SD, Gao Z, Wolf BA, Grinspan J, Lai JP et al. Interleukin-1beta upregulates functional expression of neurokinin-1 receptor (NK-1 R) via NF-kappaB in astrocytes. Glia 2004; 48: 259-266.

96 Luber-Narod J, Kage R, Leeman SE. Substance P enhances the secretion of tumor necrosis factor-alpha from neuroglial cells stimulated with lipopolysaccharide. $J$ Immunol 1994; 152: 819-824.

97 Derocq J-M, Ségui M, Blazy C, Emonds-Alt X, Le Fur G, Brelière J-C et al. Effect of substance $P$ on cytokine production by human astrocytic cells and blood mononuclear cells: characterization of novel tachykinin receptor antagonists. FEBS Lett 1996; 399: 321-325.

98 Samad TA, Moore KA, Sapirstein A, Billet S, Allchorne A, Poole S et al. Interleukin1 beta-mediated induction of Cox-2 in the CNS contributes to inflammatory pain hypersensitivity. Nature 2001; 410: 471-475.

$99 \mathrm{Ji} \mathrm{RR}$, Befort K, Brenner GJ, Woolf CJ. ERK MAP kinase activation in superficial spinal cord neurons induces prodynorphin and NK-1 upregulation and contributes to persistent inflammatory pain hypersensitivity. J Neurosci 2002; 22: 478-485.

100 Ji R-R, Kohno T, Moore KA, Woolf CJ. Central sensitization and LTP: do pain and memory share similar mechanisms? Trends Neurosci 2003; 26: 696-705.

101 Yan X, Jiang E, Weng HR. Activation of toll like receptor 4 attenuates GABA synthesis and postsynaptic GABA receptor activities in the spinal dorsal horn via releasing interleukin-1 beta. J Neuroinflammation 2015; 12: 222.

102 Jiang E, Yan X, Weng H-R. Glial glutamate transporter and glutamine synthetase regulate GABAergic synaptic strength in the spinal dorsal horn. J Neurochem 2012; 121: 526-536.

103 Zhang H, Nei H, Dougherty PM. A p38 mitogen-activated protein kinasedependent mechanism of disinhibition in spinal synaptic transmission induced by tumor necrosis factor-alpha. J Neurosci 2010; 30: 12844-12855.

104 Ahmadi S, Lippross S, Neuhuber WL, Zeilhofer HU. PGE(2) selectively blocks inhibitory glycinergic neurotransmission onto rat superficial dorsal horn neurons. Nat Neurosci 2002; 5: 34-40. 
105 Gosselin RD, Varela C, Banisadr G, Mechighel P, Rostene W, Kitabgi P et al. Constitutive expression of CCR2 chemokine receptor and inhibition by MCP-1/ CCL2 of GABA-induced currents in spinal cord neurones. J Neurochem 2005; 95 : 1023-1034.

106 Vikman KS, Duggan AW, Siddall PJ. Interferon-gamma induced disruption of GABAergic inhibition in the spinal dorsal horn in vivo. Pain 2007; 133: 18-28.

107 Houghton LA, Lea R, Jackson N, Whorwell PJ. The menstrual cycle affects rectal sensitivity in patients with irritable bowel syndrome but not healthy volunteers. Gut 2002; 50: 471-474.

108 Riley JL III, Robinson ME, Wise EA, Price D. A meta-analytic review of pain perception across the menstrual cycle. Pain 1999; 81: 225-235.

109 Palsson OS, Whitehead WE, Barghout V, Levy R, Feld A, Von Korff M et al. IBS severity and health-related quality of life improve with age in women but not in men. Am J Gastroenterol 2003; 98: S272-S272.

110 Ruigómez A, García Rodríguez LA, Johansson S, Wallander M-A. Is hormone replacement therapy associated with an increased risk of irritable bowel syndrome? Maturitas 2003; 44: 133-140.

111 Cason AM, Samuelsen CL, Berkley KJ. Estrous changes in vaginal nociception in a rat model of endometriosis. Horm Behav 2003; 44: 123-131.

112 Ji Y, Tang B, Traub RJ. The visceromotor response to colorectal distention fluctuates with the estrous cycle in rats. Neuroscience 2008; 154: 1562-1567.

113 Ball CL, Ness TJ, Randich A. Opioid blockade and inflammation reveal estrous cycle effects on visceromotor reflexes evoked by bladder distention. J Urol 2010; 184: $1529-1535$.

114 Ji Y, Tang B, Traub RJ. Modulatory effects of estrogen and progesterone on colorectal hyperalgesia in the rat. Pain 2005; 117: 433-442.

115 Berkley KJ, McAllister SL, Accius BE, Winnard KP. Endometriosis-induced vaginal hyperalgesia in the rat: effect of estropause, ovariectomy, and estradiol replacement. Pain 2007; 132(Suppl 1): S150-S159.

116 Robbins MT, Mebane $H$, Ball $C L$, Shaffer AD, Ness TJ. Effect of estrogen on bladder nociception in rats. J Urol 2010; 183: 1201-1205.

117 Traub RJ, Ji Y. Sex differences and hormonal modulation of deep tissue pain. Front Neuroendocrinol 2013; 34: 350-366.

118 Tang B, Ji Y, Traub RJ. Estrogen alters spinal NMDA receptor activity via a PKA signaling pathway in a visceral pain model in the rat. Pain 2008; 137: 540-549.

$119 \mathrm{Ji} \mathrm{Y,} \mathrm{Tang} \mathrm{B,} \mathrm{Traub} \mathrm{RJ.} \mathrm{Spinal} \mathrm{estrogen} \mathrm{receptor} \mathrm{alpha} \mathrm{mediates} \mathrm{estradiol-induced}$ pronociception in a visceral pain model in the rat. Pain 2011; 152: 1182-1191.

120 Lewis SS, Hutchinson MR, Frick MM, Zhang Y, Maier SF, Sammakia T et al. Select steroid hormone glucuronide metabolites can cause toll-like receptor 4 activation and enhanced pain. Brain Behav Immun 2015; 44: 128-136.

121 Loram LC, Sholar PW, Taylor FR, Wiesler JL, Babb JA, Strand KA et al. Sex and estradiol influence glial pro-inflammatory responses to lipopolysaccharide in rats. Psychoneuroendocrinology 2012; 37: 1688-1699.

122 Soucy G, Boivin G, Labrie F, Rivest S. Estradiol is required for a proper immune response to bacterial and viral pathogens in the female brain. J Immunol 2005; 174: 6391-6398.

123 Calippe B, Douin-Echinard V, Delpy L, Laffargue M, Lelu K, Krust A et al. 17Betaestradiol promotes TLR4-triggered proinflammatory mediator production through direct estrogen receptor alpha signaling in macrophages in vivo. J Immunol 2010; 185: 1169-1176.

124 Wegner A, Elsenbruch S, Rebernik L, Roderigo T, Engelbrecht E, Jager M et al. Inflammation-induced pain sensitization in men and women: does sex matter in experimental endotoxemia? Pain 2015; 156: 1954-1964.

125 Karshikoff B, Lekander M, Soop A, Lindstedt F, Ingvar M, Kosek E et al. Modality and sex differences in pain sensitivity during human endotoxemia. Brain Behav Immun 2015; 46: 35-43.

126 Sorge RE, LaCroix-Fralish ML, Tuttle AH, Sotocinal SG, Austin JS, Ritchie J et al. Spinal cord Toll-like receptor 4 mediates inflammatory and neuropathic hypersensitivity in male but not female mice. J Neurosci 2011; 31: 15450-15454.

127 Stokes JA, Cheung J, Eddinger K, Corr M, Yaksh TL. Toll-like receptor signaling adapter proteins govern spread of neuropathic pain and recovery following nerve injury in male mice. J Neuroinflammation 2013; 10: 148.

128 Taves S, Berta T, Liu DL, Gan S, Chen G, Kim YH et al. Spinal inhibition of p38 MAP kinase reduces inflammatory and neuropathic pain in male but not female mice: Sex-dependent microglial signaling in the spinal cord. Brain Behav Immun 2015; 55: 70-81.

129 Sorge RE, Mapplebeck JC, Rosen S, Beggs S, Taves S, Alexander JK et al. Different immune cells mediate mechanical pain hypersensitivity in male and female mice. Nat Neurosci 2015; 18: 1081-1083.

130 Reddy J, Waldner H, Zhang X, Illes Z, Wucherpfennig KW, Sobel RA et al. Cutting edge: $C D 4+C D 25+$ regulatory $T$ cells contribute to gender differences in susceptibility to experimental autoimmune encephalomyelitis. J Immunol 2005; 175: 5591-5595.

131 Amandusson A, Blomqvist A. Estrogenic influences in pain processing. Front Neuroendocrinol 2013; 34: 329-349.
132 Aloisi AM, Bonifazi M. Sex hormones, central nervous system and pain. Horm Behav 2006; 50: 1-7.

133 Craft RM. Modulation of pain by estrogens. Pain 2007; 132(Suppl 1): S3-12.

134 Sanoja R, Cervero F. Estrogen-dependent changes in visceral afferent sensitivity. Auton Neurosci 2010; 153: 84-89.

135 Fillingim RB, Ness TJ. Sex-related hormonal influences on pain and analgesic responses. Neurosci Biobehav Rev 2000; 24: 485-501.

136 Giamberardino MA, Vecchiet L. Visceral pain, referred hyperalgesia and outcome: new concepts. Eur J Anaesthesiol Suppl 1995; 10: 61-66.

137 Cervero F, Laird JM. Visceral pain. Lancet 1999; 353: 2145-2148.

138 Gebhart GF, Ness TJ. Central mechanisms of visceral pain. Can J Physiol Pharmacol 1991; 69: 627-634.

139 Lu CL. Spinal microglia: A potential target in the treatment of chronic visceral pain. J Chin Med Assoc 2014; 77: 3-9.

140 Mathias SD, Kuppermann M, Liberman RF, Lipschutz RC, Steege JF. Chronic pelvic pain: prevalence, health-related quality of life, and economic correlates. Obstet Gynecol 1996; 87: 321-327.

141 Grace VM, Zondervan KT. Chronic pelvic pain in New Zealand: prevalence, pain severity, diagnoses and use of the health services. Aust N Z J Public Health 2004; 28: $369-375$.

142 Suskind AM, Berry SH, Ewing BA, Elliott MN, Suttorp MJ, Clemens JQ. The prevalence and overlap of interstitial cystitis/bladder pain syndrome and chronic prostatitis/chronic pelvic pain syndrome in men: results of the RAND Interstitial Cystitis Epidemiology Male Study. J Urol 2013; 189: 141-145.

143 Ejike CECC, Ezeanyika LUS. Prevalence of chronic prostatitis symptoms in a randomly surveyed adult population of urban-community-dwelling Nigerian males. Int J Urol 2008; 15: 340-343.

144 Latthe P, Mignini L, Gray R, Hills R, Khan K. Factors predisposing women to chronic pelvic pain: systematic review. Br Med J 2006; 332: 749-755.

145 Curran NC. Commentary on the influence of gender on the management of chronic pelvic pain. BJOG 2015; 122: 766-768.

146 Zhang H, Liu L, Yang Z, Pan J, Chen Z, Fang Q et al. P2X7 receptor mediates activation of microglial cells in prostate of chemically irritated rats. Int Braz J Urol 2013; 39: 276-285.

147 Wong L, Done JD, Schaeffer AJ, Thumbikat P. Experimental autoimmune prostatitis induces microglial activation in the spinal cord. Prostate 2015; 75: 50-59.

148 Chen Z, Xie F, Bao M, Li X, Chao Y, Lin C et al. Activation of p38 MAPK in the rostral ventromedial medulla by visceral noxious inputs transmitted via the dorsal columns may contribute to pelvic organ cross-sensitization in rats with endometriosis. Neuroscience 2015; 291: 272-278.

149 Wang Y, Zhang M, Xie F, Li X, Bao M, Yang N et al. Upregulation of alpha(2)delta1 calcium channel subunit in the spinal cord contributes to pelvic organ crosssensitization in a rat model of experimentally-induced endometriosis. Neurochem Res 2015; 40: 1267-1273.

150 Miranda A, Mickle A, Schmidt J, Zhang Z, Shaker R, Banerjee B et al. Neonatal cystitis-induced colonic hypersensitivity in adult rats: a model of viscero-visceral convergence. Neurogastroenterol Motil 2011; 23: 683-e281.

151 Yoshikawa S, Kawamorita N, Oguchi T, Funahashi Y, Tyagi P, Chancellor MB et al. Pelvic organ cross-sensitization to enhance bladder and urethral pain behaviors in rats with experimental colitis. Neuroscience 2015; 284: 422-429.

152 Podolsky DK. Inflammatory bowel disease (1). N Engl J Med 1991; 325: 928-937.

153 Kappelman MD, Rifas-Shiman SL, Kleinman K, Ollendorf D, Bousvaros A, Grand $\mathrm{RJ}$ et al. The prevalence and geographic distribution of crohn's disease and ulcerative colitis in the United States. Clin Gastroenterol Hepatol 2007; 5: 1424-1429.

154 Bernstein CN, Wajda A, Svenson LW, MacKenzie A, Koehoorn M, Jackson M et al. The epidemiology of inflammatory bowel disease in Canada: a populationbased study. Am J Gastroenterol 2006; 101: 1559-1568.

155 Riazi K, Galic MA, Kuzmiski JB, Ho W, Sharkey KA, Pittman QJ. Microglial activation and TNFalpha production mediate altered CNS excitability following peripheral inflammation. Proc Natl Acad Sci USA 2008; 105: 17151-17156.

156 Kannampalli P, Pochiraju S, Bruckert M, Shaker R, Banerjee B, Sengupta JN. Analgesic effect of minocycline in rat model of inflammation-induced visceral pain. Eur J Pharmacol 2014; 727: 87-98.

157 Song DD, Li Y, Tang D, Huang LY, Yuan YZ. Neuron-glial communication mediated by TNF-alpha and glial activation in dorsal root ganglia in visceral inflammatory hypersensitivity. Am J Physiol Gastrointest Liver Physiol 2014; 306: G788-G795.

158 Huang TY, Belzer V, Hanani M. Gap junctions in dorsal root ganglia: possible contribution to visceral pain. Eur J Pain 2010; 14: 49.e41-11.

159 Vella M, Robinson D, Cardozo L. Painful bladder syndrome. Obstet Gynaecol Reprod Med 2015; 25: 222-228.

160 Berry SH, Elliott MN, Suttorp M, Bogart LM, Stoto MA, Eggers P et al. Prevalence of symptoms of bladder pain syndrome/interstitial cystitis among adult females in the United States. J Urol 2011; 186: 540-544. 
161 Birder LA, Wolf-Johnston AS, Chib MK, Buffington CA, Roppolo JR, HannaMitchell AT. Beyond neurons: involvement of urothelial and glial cells in bladder function. Neurourol Urodyn 2010; 29: 88-96.

162 Schrepf A, O'Donnell M, Luo Y, Bradley CS, Kreder K, Lutgendorf S. Inflammation and inflammatory control in interstitial cystitis/bladder pain syndrome: associations with painful symptoms. Pain 2014; 155: 1755-1761.

163 Schrepf A, Bradley CS, O'Donnell M, Luo Y, Harte SE, Kreder K et al. Toll-like receptor 4 and comorbid pain in interstitial cystitis/bladder pain syndrome: a multidisciplinary approach to the study of chronic pelvic pain research network study. Brain Behav Immun 2015; 49: 66-74.

164 Kwok YH, Tuke J, Nicotra LL, Grace PM, Rolan PE, Hutchinson MR. TLR 2 and 4 responsiveness from isolated peripheral blood mononuclear cells from rats and humans as potential chronic pain biomarkers. PLoS One 2013; 8: e77799.

165 Eskenazi B, Warner ML. Epidemiology of endometriosis. Obstet Gynecol Clin North Am 1997; 24: 235-258.

166 Janssen EB, Rijkers AC, Hoppenbrouwers K, Meuleman C, D'Hooghe TM. Prevalence of endometriosis diagnosed by laparoscopy in adolescents with dysmenorrhea or chronic pelvic pain: a systematic review. Hum Reprod Update 2013; 19: $570-582$.

167 Abbott JA, Hawe J, Clayton RD, Garry R. The effects and effectiveness of laparoscopic excision of endometriosis: a prospective study with 2-5 year follow-up. Hum Reprod 2003; 18: 1922-1927.

168 Gruppo Italiano per lo Studio dell'Endometriosi. Relationship between stage, site and morphological characteristics of pelvic endometriosis and pain. Hum Reprod 2001; 16: 2668-2671.

169 Vercellini P, Fedele L, Aimi G, Pietropaolo G, Consonni D, Crosignani PG. Association between endometriosis stage, lesion type, patient characteristics and severity of pelvic pain symptoms: a multivariate analysis of over 1000 patients. Hum Reprod 2007; 22: 266-271.

170 Brawn J, Morotti M, Zondervan KT, Becker CM, Vincent K. Central changes associated with chronic pelvic pain and endometriosis. Hum Reprod Update 2014; 20: 737-747.

171 Morotti M, Vincent K, Brawn J, Zondervan KT, Becker CM. Peripheral changes in endometriosis-associated pain. Hum Reprod Update 2014; 20: 717-736.

172 Bajaj P, Bajaj P, Madsen H, Arendt-Nielsen L. Endometriosis is associated with central sensitization: a psychophysical controlled study. J Pain 2003; 4: 372-380.

173 Berkley KJ, Rapkin AJ, Papka RE. The pains of endometriosis. Science 2005; 308: 1587-1589.

174 Olovsson M. Immunological aspects of endometriosis: an update. Am J Reprod Immunol 2011; 66(Suppl 1): 101-104.

175 Khan KN, Kitajima M, Fujishita A, Nakashima M, Masuzaki H. Toll-like receptor system and endometriosis. J Obstet Gynaecol Res 2013; 39: 1281-1292.

176 Khan KN, Kitajima M, Imamura T, Hiraki K, Fujishita A, Sekine I et al. Toll-like receptor 4-mediated growth of endometriosis by human heat-shock protein 70 . Hum Reprod 2008; 23: 2210-2219.

177 Allhorn S, Boing C, Koch AA, Kimmig R, Gashaw I. TLR3 and TLR4 expression in healthy and diseased human endometrium. Reprod Biol Endocrinol 2008; 6: 40.

178 Yeo SG, Won YS, Lee HY, Kim Yl, Lee JW, Park DC. Increased expression of pattern recognition receptors and nitric oxide synthase in patients with endometriosis. Int J Med Sci 2013; 10: 1199-1208.

179 Capobianco A, Rovere-Querini P. Endometriosis, a disease of the macrophage. Front Immunol 2013; 4: 9.

180 Khan KN, Kitajima M, Hiraki K, Fujishita A, Sekine I, Ishimaru T et al. Immunopathogenesis of pelvic endometriosis: role of hepatocyte growth factor, macrophages and ovarian steroids. Am J Reprod Immunol 2008; 60: 383-404.

181 Sampson JA. Peritoneal endometriosis due to the menstrual dissemination of endometrial tissue into the peritoneal cavity. Am J Obstet Gynecol 1927; 14: 422-469.

182 Blumenkrantz MJ, Gallagher N, Bashore RA, Tenckhoff H. Retrograde menstruation in women undergoing chronic peritoneal dialysis. Obstet Gynecol 1981; 57: $667-670$

183 Garcia Rodriguez LA, Ruigomez A, Panes J. Acute gastroenteritis is followed by an increased risk of inflammatory bowel disease. Gastroenterology 2006; 130: 1588-1594.

184 Foreman JC. Peptides and neurogenic inflammation. Br Med Bull 1987; 43: 386-400.

185 O'Connor TM, O'Connell J, O'Brien DI, Goode T, Bredin CP, Shanahan F. The role of substance $P$ in inflammatory disease. J Cell Physiol 2004; 201: 167-180.

186 Xanthos DN, Sandkuhler J. Neurogenic neuroinflammation: inflammatory CNS reactions in response to neuronal activity. Nat Rev Neurosci 2014; 15: 43-53.

187 Richardson JD, Vasko MR. Cellular mechanisms of neurogenic inflammation. J Pharmacol Exp Ther 2002; 302: 839-845.

188 Rees H, Sluka KA, Westlund KN, Willis WD. The role of glutamate and GABA receptors in the generation of dorsal root reflexes by acute arthritis in the anaesthetized rat. J Physiol 1995; 484, Pt 2 437-445.
189 Sluka KA, Rees H, Westlund KN, Willis WD. Fiber types contributing to dorsal root reflexes induced by joint inflammation in cats and monkeys. J Neurophysiol 1995; 74: 981-989.

190 Willis WD Jr. Dorsal root potentials and dorsal root reflexes: a doubleedged sword. Exp Brain Res 1999; 124: 395-421.

191 Lin Q, Wu J, Willis WD. Dorsal root reflexes and cutaneous neurogenic inflammation after intradermal injection of capsaicin in rats. J Neurophysiol 1999; 82: 2602-2611.

192 Lin Q, Zou X, Willis WD. Adelta and C primary afferents convey dorsal root reflexes after intradermal injection of capsaicin in rats. J Neurophysio/ 2000; 84: 2695-2698.

193 Weng HR, Dougherty PM. Response properties of dorsal root reflexes in cutaneous $C$ fibers before and after intradermal capsaicin injection in rats. Neuroscience 2005 ; 132: 823-831.

194 Chen HS, Lei J, He X, Wang Y, Wen WW, Wei XZ et al. Pivotal involvement of neurogenic mechanism in subcutaneous bee venom-induced inflammation and allodynia in unanesthetized conscious rats. Exp Neurol 2006; 200: 386-391.

195 Lin Q, Li D, Xu X, Zou X, Fang L. Roles of TRPV1 and neuropeptidergic receptors in dorsal root reflex-mediated neurogenic inflammation induced by intradermal injection of capsaicin. Mol Pain 2007; 3: 30.

196 Wei H, Koivisto A, Pertovaara A. Spinal TRPA1 ion channels contribute to cutaneous neurogenic inflammation in the rat. Neurosci Lett 2010; 479: 253-256.

197 Rees H, Sluka KA, Westlund KN, Willis WD. Do dorsal root reflexes augment peripheral inflammation? Neuroreport 1994; 5: 821-824.

198 Rees H, Sluka KA, Lu Y, Westlund KN, Willis WD. Dorsal root reflexes in articular afferents occur bilaterally in a chronic model of arthritis in rats. J Neurophysiol 1996; 76: 4190-4193.

199 Zhang LP, Chen Y, Clark BP, Sher E, Westlund KN. The role of type 1 metabotropic glutamate receptors in the generation of dorsal root reflexes induced by acute arthritis or the spinal infusion of 4-aminopyridine in the anesthetized rat. $J$ Pain 2000; 1: 151-161.

200 Lin P, Wu XY, Pan H, Jiang HJ, Mei L. Rat colitis induced by intrathecal injection of substance P. Sheng Li Xue Bao 2009; 61: 331-338.

201 Kemler MA, Barendse GA, Van Kleef M. Relapsing ulcerative colitis associated with spinal cord stimulation. Gastroenterology 1999; 117: 215-217.

202 Barbara G, De Giorgio R, Stanghellini V, Gionchetti P, Campieri M, Corinaldesi R. Relapsing ulcerative colitis after spinal cord stimulation: a case of intestinal neurogenic inflammation? Gastroenterology 1999; 117: 1256-1257.

203 Peck OC, Wood JD. Brain-gut interactions in ulcerative colitis. Gastroenterology 2000; 118: 807-808.

204 Boyle DL, Jones TL, Hammaker D, Svensson Cl, Rosengren S, Albani S et al. Regulation of peripheral inflammation by spinal p38 MAP kinase in rats. PLoS Med 2006; 3: e338.

205 Fiorentino PM, Tallents RH, Miller JN, Brouxhon SM, O'Banion MK, Puzas JE et al. Spinal interleukin-1beta in a mouse model of arthritis and joint pain. Arthritis Rheum 2008; 58: 3100-3109.

206 Wesselmann U. Neurogenic inflammation and chronic pelvic pain. World J Urol 2001; 19: 180-185.

207 Jasmin L, Janni G, Manz HJ, Rabkin SD. Activation of CNS circuits producing a neurogenic cystitis: evidence for centrally induced peripheral inflammation. $J$ Neurosci 1998; 18: 10016-10029.

208 Engel MA, Becker C, Reeh PW, Neurath MF. Role of sensory neurons in colitis: increasing evidence for a neuroimmune link in the gut. Inflamm Bowel Dis 2011; 17: $1030-1033$.

209 Origoni M, Leone Roberti Maggiore U, Salvatore S, Candiani M. Neurobiological mechanisms of pelvic pain. Biomed Res Int 2014; 2014: 903848.

210 Laux-Biehlmann A, d'Hooghe T, Zollner TM. Menstruation pulls the trigger for inflammation and pain in endometriosis. Trends Pharmacol Sci 2015; 36: 270-276.

211 McKinnon BD, Bertschi D, Bersinger NA, Mueller MD. Inflammation and nerve fiber interaction in endometriotic pain. Trends Endocrinol Metab 2015; 26: 1-10.

212 Hains LE, Loram LC, Weiseler JL, Frank MG, Bloss EB, Sholar P et al. Pain intensity and duration can be enhanced by prior challenge: initial evidence suggestive of a role of microglial priming. J Pain 2010; 11: 1004-1014.

213 Pierce AN, Ryals JM, Wang R, Christianson JA. Vaginal hypersensitivity and hypothalamic-pituitary-adrenal axis dysfunction as a result of neonatal maternal separation in female mice. Neuroscience 2014; 263: 216-230.

214 Pierce AN, Zhang Z, Fuentes IM, Wang R, Ryals JM, Christianson JA. Neonatal vaginal irritation results in long-term visceral and somatic hypersensitivity and increased hypothalamic-pituitary-adrenal axis output in female mice. Pain 2015; 156: 2021-2031.

215 Ness TJ, Randich A. Neonatal bladder inflammation alters activity of adult rat spinal visceral nociceptive neurons. Neurosci Lett 2010; 472: 210-214.

216 Rosztoczy A, Fioramonti J, Jarmay K, Barreau F, Wittmann T, Bueno L. Influence of sex and experimental protocol on the effect of maternal deprivation on rectal sensitivity to distension in the adult rat. Neurogastroenterol Motil 2003; 15: $679-686$. 
217 D'Hooghe TM, Bambra CS, Raeymaekers BM, Koninckx PR. Development of spontaneous endometriosis in baboons. Obstet Gynecol 1996; 88: 462-466.

218 Coe CL, Lemieux AM, Rier SE, Uno H, Zimbric ML. Profile of endometriosis in the aging female rhesus monkey. J Gerontol A Biol Sci Med Sci 1998; 53: M3-M7.

219 White HD, Robinson TD. A novel use for testosterone to treat central sensitization of chronic pain in fibromyalgia patients. Int Immunopharmacol 2015; 27: 244-248.

220 Aloisi AM, Bachiocco V, Costantino A, Stefani R, Ceccarelli I, Bertaccini A et al. Cross-sex hormone administration changes pain in transsexual women and men. Pain 2007; 132(Supplement 1): S60-S67.

221 Ji RR, Xu ZZ, Gao YJ. Emerging targets in neuroinflammation-driven chronic pain. Nat Rev Drug Discov 2014; 13: 533-548.

222 Banati RB, Cagnin A, Brooks DJ, Gunn RN, Myers R, Jones T et al. Long-term transsynaptic glial responses in the human thalamus after peripheral nerve injury. Neuroreport 2001; 12: 3439-3442.

223 Albrecht D, Loggia M, Borra R, Hooker J, Opalacz A, Mao J et al. Activation of spinal glia in sciatica; a pilot [11C]PBR28 study. J Nucl Med 2015; 56(supplement 3): 1557.
224 Loggia ML, Chonde DB, Akeju O, Arabasz G, Catana C, Edwards RR et al. Evidence for brain glial activation in chronic pain patients. Brain 2015; 138(Pt 3): 604-615.

225 Mogil JS, Davis KD, Derbyshire SW. The necessity of animal models in pain research. Pain 2010; 151: 12-17.

226 Borsook D, Hargreaves R, Bountra C, Porreca F. Lost but making progresswhere will new analgesic drugs come from? Sci Transl Med 2014; 6: 249 sr243.

This work is licensed under a Creative Commons Attribution 4.0 International License. The images or other third party material in this article are included in the article's Creative Commons license, unless indicated otherwise in the credit line; if the material is not included under the Creative Commons license, users will need to obtain permission from the license holder to reproduce the material. To view a copy of this license, visit http://creativecommons.org/licenses/ by/4.0/

(c) The Author(s) 2016 